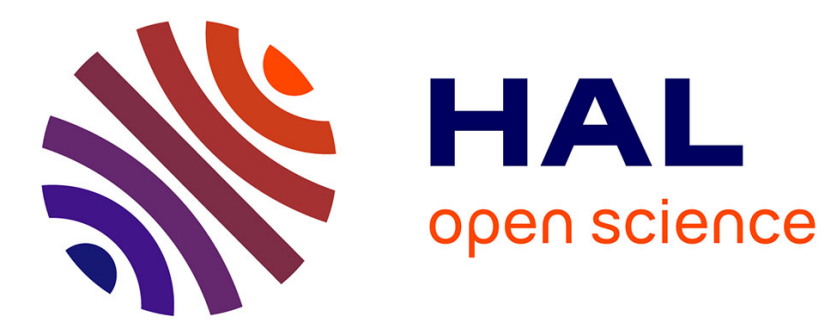

\title{
Three-dimensional seismo-tectonics in the Po Valley basin, Northern Italy
}

Claudio Turrini, Pamela Angeloni, Olivier Lacombe, Maurizio Ponton, François Roure

\section{- To cite this version:}

Claudio Turrini, Pamela Angeloni, Olivier Lacombe, Maurizio Ponton, François Roure. Threedimensional seismo-tectonics in the Po Valley basin, Northern Italy. Tectonophysics, 2015, 661, pp.156-179. 10.1016/j.tecto.2015.08.033 . hal-01247987

\section{HAL Id: hal-01247987 \\ https://hal.science/hal-01247987}

Submitted on 23 Dec 2015

HAL is a multi-disciplinary open access archive for the deposit and dissemination of scientific research documents, whether they are published or not. The documents may come from teaching and research institutions in France or abroad, or from public or private research centers.
L'archive ouverte pluridisciplinaire HAL, est destinée au dépôt et à la diffusion de documents scientifiques de niveau recherche, publiés ou non, émanant des établissements d'enseignement et de recherche français ou étrangers, des laboratoires publics ou privés. 


\section{Three-dimensional seismo-tectonics in the Po Valley basin, Northern Italy}

Claudio Turrini ${ }^{\mathrm{a}, 1}$

clturri@wanadoo.fr

Pamela Angelonib

Olivier Lacombe $e^{\mathrm{c}, \mathrm{d}}$

Maurizio Ponton ${ }^{e}$

François Roure ${ }^{\mathrm{tg}}$

aCTGeolConsulting, 78100- St._Germain-en-Laye, France

bVia Antonio Perfetti 25, 00133 Roma, Italy

'Sorbonne Universités, UPMC Univ Paris 06, UMR 7193, ISTEP, F-75005- Paris, France

${ }^{d}$ CNRS, UMR 7193, ISTEP, F-75005- Paris, France

eDipartimento di Matematica e Geoscienze, Università degli Studi di Trieste, Trieste, Italy

IIFP-EN, Rueil-Malmaison, France

gUtrecht University, The Netherlands

${ }^{1}$ Tel.: + 33672391235

Abstract

The Po Valley (Northern Italy) is a composite foreland__foredeep basin caught in between the Southern Alps and Northern Apennine mountain belts.

By integrating the 3D structural model of the region with the public earthquake dataset, the seismo-tectonics of the basin is shown at different scales of observation.

The three-dimensional geo-volume is used to review the seismicity around the region and validate the structure_earthquake association for such a complex tectonic framework.

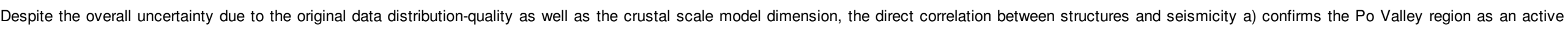
tectonic system $\overline{7}$ and $\mathrm{b}$ ) allows the whole structural architecture to be revised by a unique three-dimensional perspective and approach.

This study also indicates that 3D methodology is a powerful tool for a better understanding of highly complex seismo-tectonic situations at both regional and local scalescales.

Keywords: Seismo-tectonics; 3D models; Earthquakes; Po Valley; Northern Italy; Southern Alps; Northern Apennines

\section{Introduction}

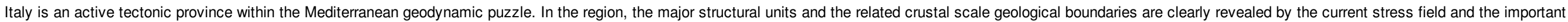

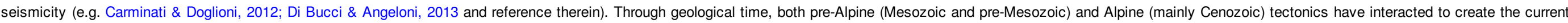

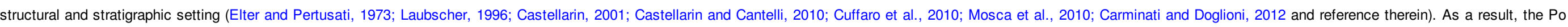

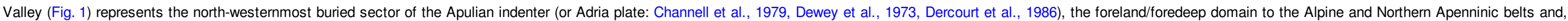




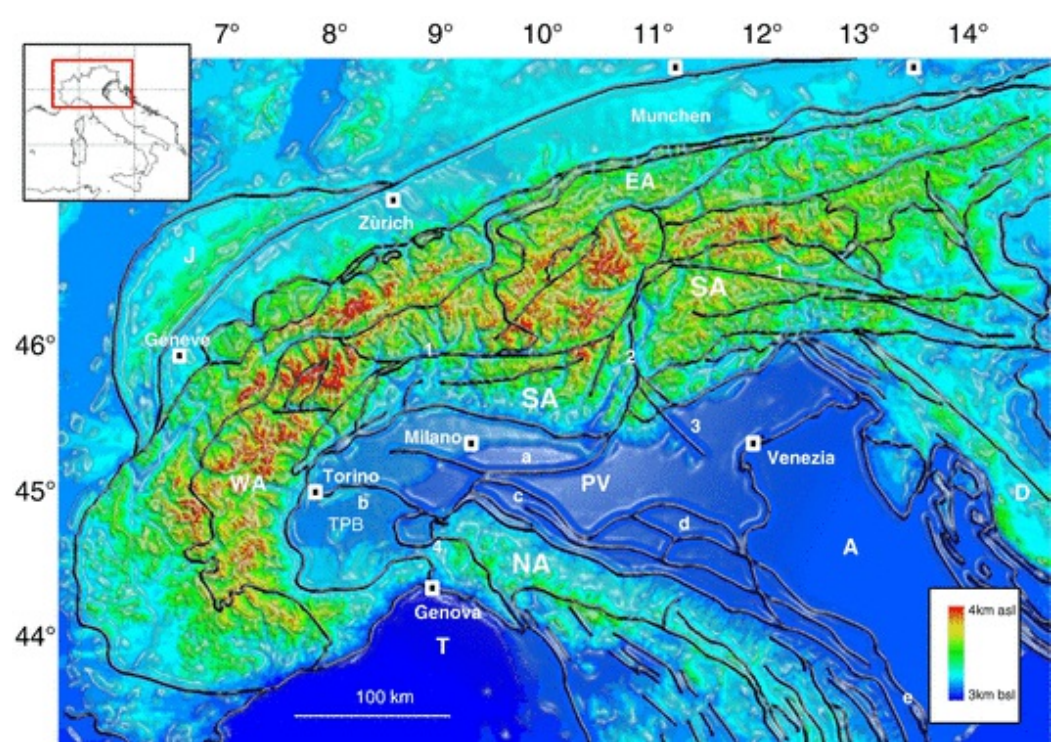

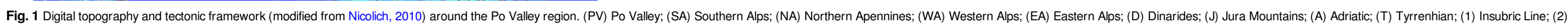

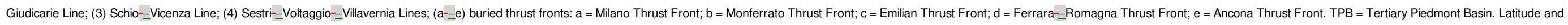
Longitude values are North and East of Greenwich. Grid in the meertinset map is $500 \mathrm{~km}$.

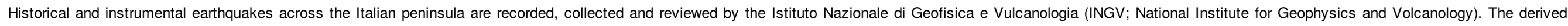
catalogues are constantly updated at each new seismic event and both initial and (re)processed data are available to the public, on the institution's website (http://www.ingv.it/it/).

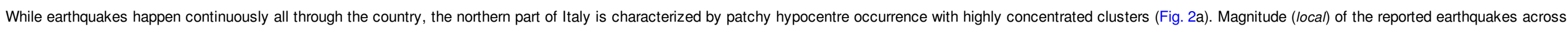

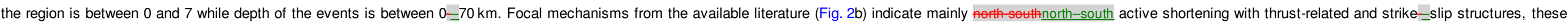

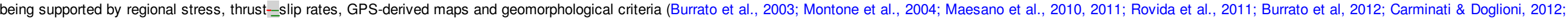
Michetti et al., 2012; Di Bucci \& Angeloni, 2013; Maesano et al., 2013, 2014; and all references therein). 

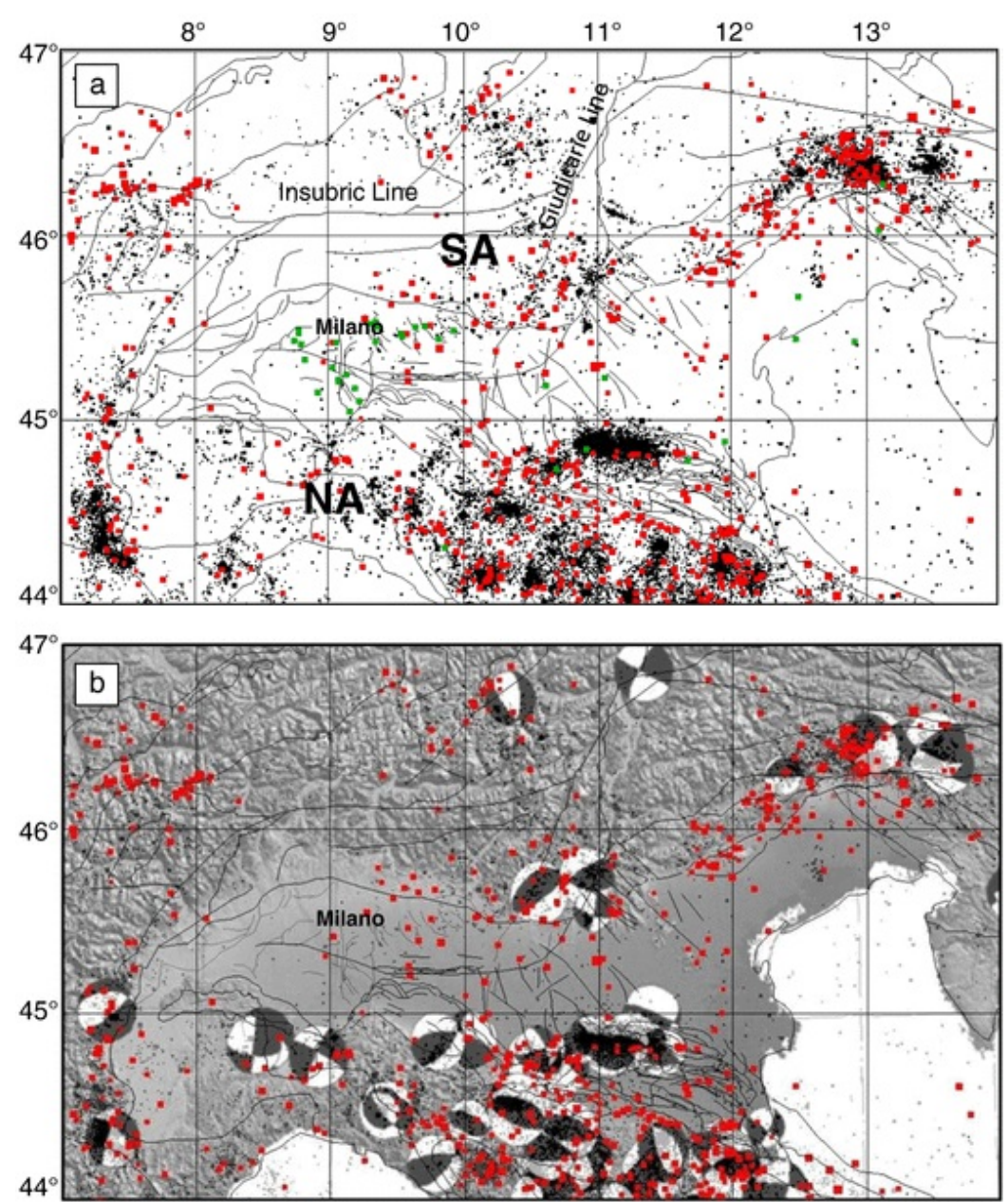

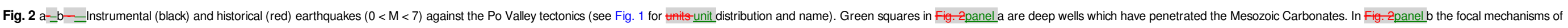
the major events ( $M>5$; from Di Bucci and Angeloni, 2013) are indicated. (For interpretation of the references to colour in this figure legend, the reader is referred to the web version of this article.)

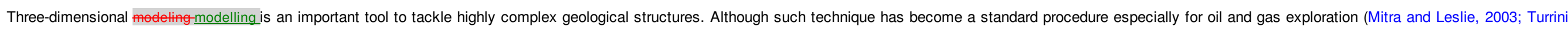

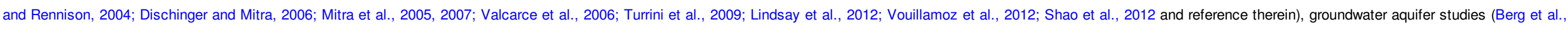

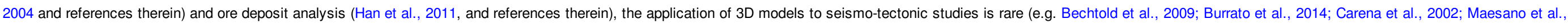
2014). Hence, schematic cross-sections or simple map-view projections constitute the classic tools for the analysis of structures-versus-earthquakes associations.

As follow-up to the recent Po Valley 3D model (Turrini et al., 2014), this study aims to illustrate and discuss the structures and the seismicity of the region from crustal to local scale.

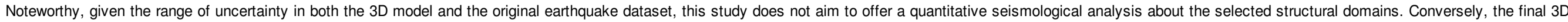
geo-volume may represent a powerful tool in the unraveling unravelling of the basin seismo-tectonic complexity.

\section{Regional framework of the Po Valley}




\subsection{Structures, stratigraphy \& exploration}

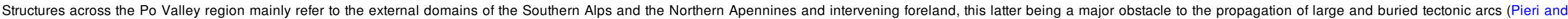

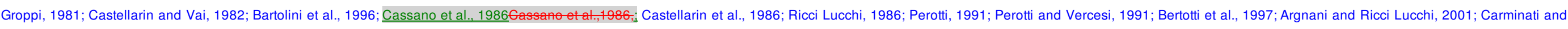

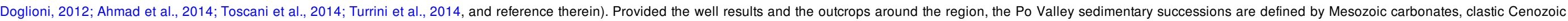

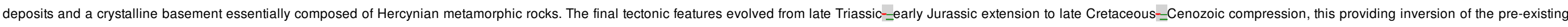

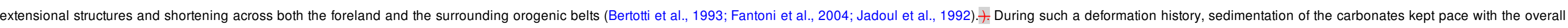

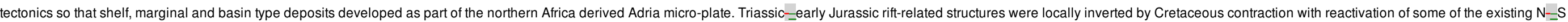

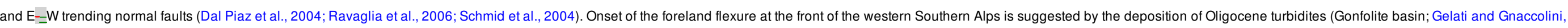

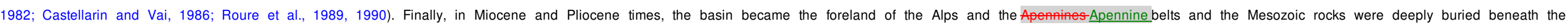
Palogone-Palaeogene-Neogene clastics and the associated for

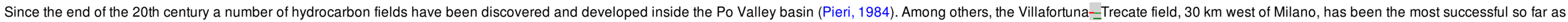

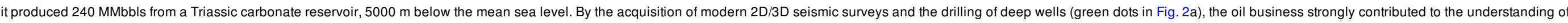

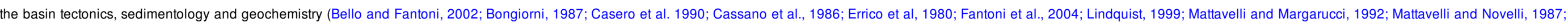
Nardon et al., 1991; Pieri, 1984; Pieri and Groppi, 1981).

\subsection{Seismo-tectonic setting}

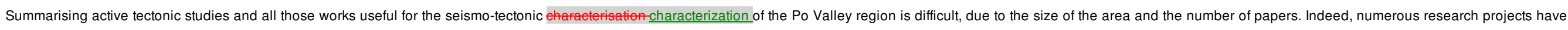
increasingly tackled the Po Valley neotectonic setting, this being especially due to the recent earthquake activity in the region (Michetti et al., 2012; Vannoli et al., 2014).

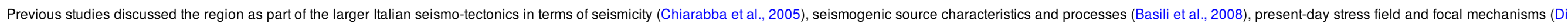

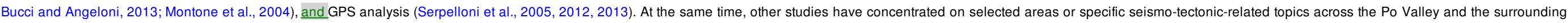
regions. Among these many studies, below we put emphasis on those which provided key constraints to the performed 3D modelling, loosely grouped by tectonic domain (foreland, Southern Alps, Northern Apennines).

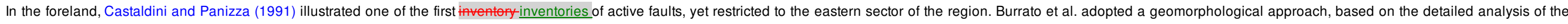

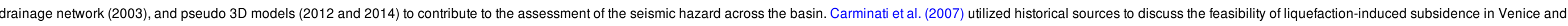

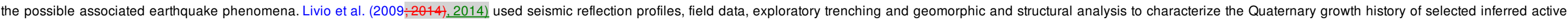

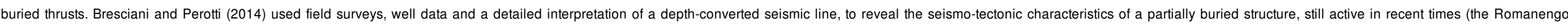

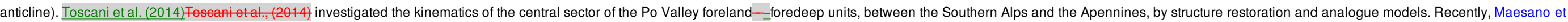

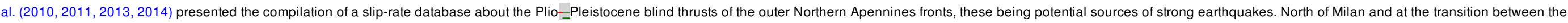
Southern Alps and the foreland units, Scardia et al. (2014) documented the tectonics and earthquake activity which deformed that domain since the Pliocene to the present day.

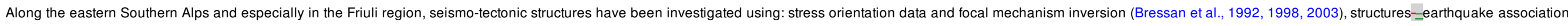

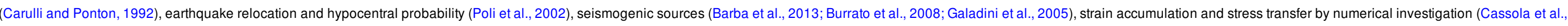

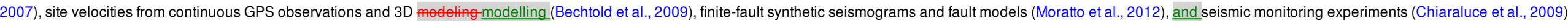

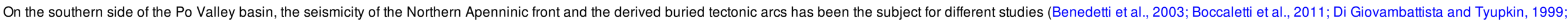

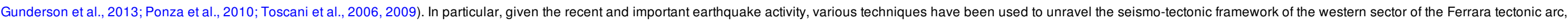

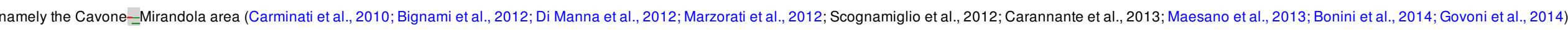

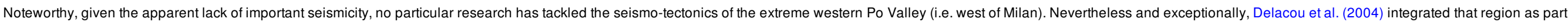
of the seismo-tectonics analysis of the western/central Alps using a synthesis of the available and most reliable focal mechanisms. 


\section{Data \& methodology}

\subsection{Data}

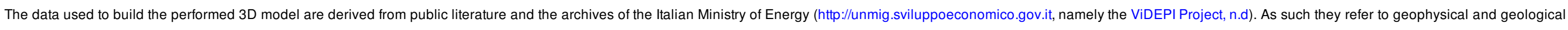

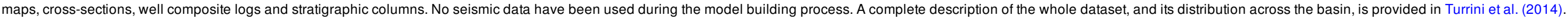

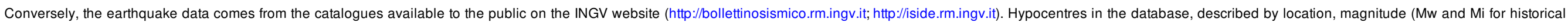
and instrumental earthquake respectively) and depth, can be essentially classified as:

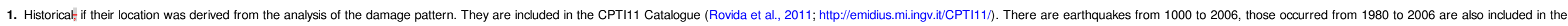
instrumental catalogues. This is a parametric catalogue with epicentral coordinates, but not depth, and magnitude expressed as moment magnitude $\left(\mathrm{M}_{\mathrm{w}}\right)$

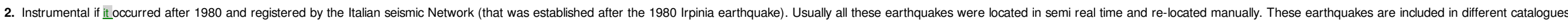

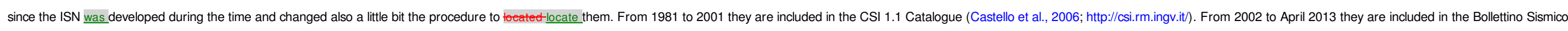
Italiano and downloadable from http://bollettinosismico.rm.ingv.it/ and http://iside.rm.ingv.it/. The latter web-site includes also the real-time seismicity not revised by the analyst seismologists (April 2014 up to now).

\subsection{Methodology}

The methodology adopted so far refers to four different phases of data collection, editing and analysis.

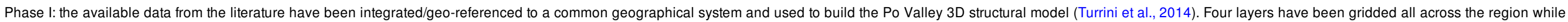
key cross-sections, depth-slices and isopach maps have been constructed to analyse-analyze the final model. Both the model building and the related analysis have been performed using the MOVE software.

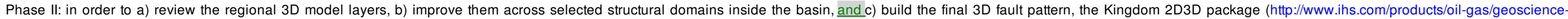

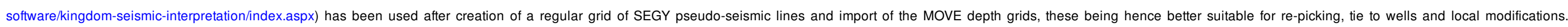
Specifically, the fault building process was performed by:

1. projection of public map fault traces on the model grid layers

2. analysis and slicing of the structural geometries from the $3 \mathrm{D}$ model depth-grids and along the available well paths

3. gridding of the final $3 \mathrm{D}$ fault plane.

Further, the Kingdom surface-validation tool was used to allow the 3D surface compatibility of the

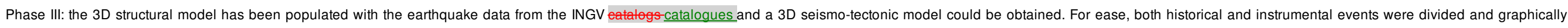

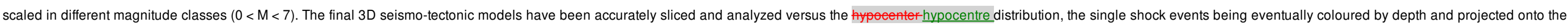
model vertical slices from the most suitable distances.

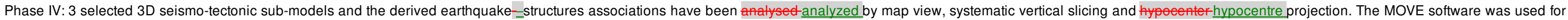
$3 \mathrm{D}$ visualization and rendering of the model structures and earthquake events.

\section{Model and data uncertainty}

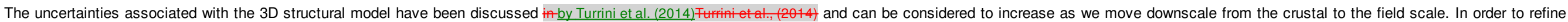

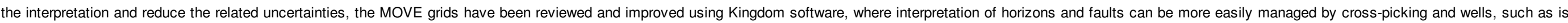

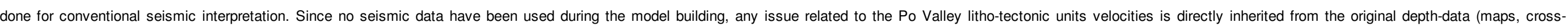




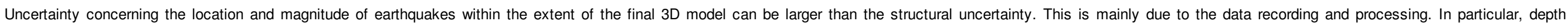

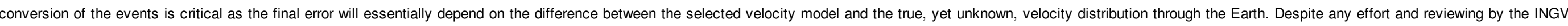

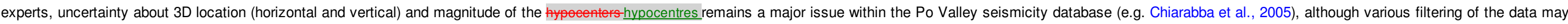

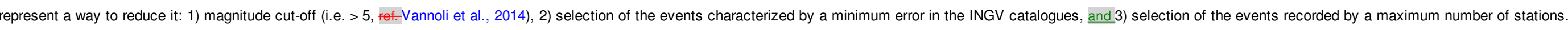

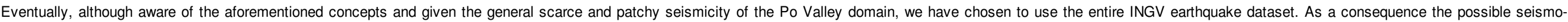
tectonic scenarios have been analyzed in thelight of the performed 3D perspective and our experienced/knowledge of the basin. The process suggested that:

1. The validity of the Po Valley structure_earthquake integration seems, at present, acceptable at the regional scale, whereas it should be considered possible at a smaller scale (e.g. across the selected sub-domains);

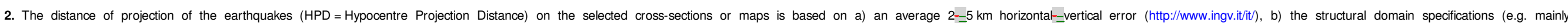
compression/extension?), c) the 3D structures (geometries, dimensions), and d) the distribution/density of the surrounding earthquakes;

3. This indicates that the earthquakes-structures integration and the derived comparative analysis have the potential to act as a decisive tool for uncertainty reduction and reciprocal validation of the data used to build the final Po Valley $3 \mathrm{D}$ seismo-tectonic model.

\section{Seismo-tectonics across the 3D Po Valley geo-volume}

\subsection{D model and regional seismicity}

Once the outcrop structural trends and the subsurface model layers are put against the entire earthquake dataset, the 3D seismo-tectonic framework across and around the Po Valley is immediately revealed.

In general, the model confirms the positive correlation among the crustal tectonics and the most important earthquake events (Fig. 3a). 
a

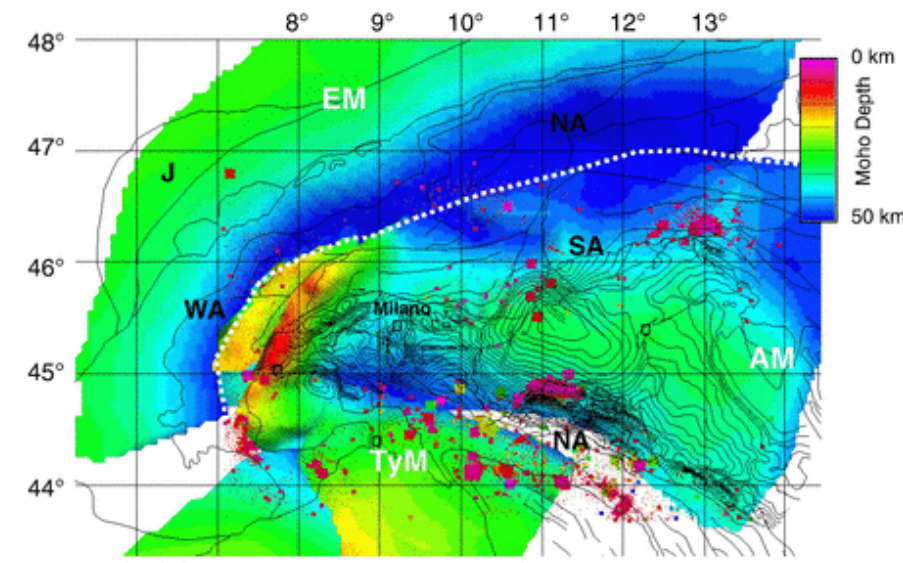

b

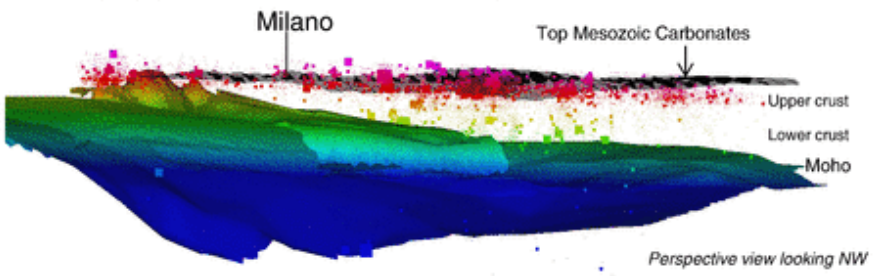

C

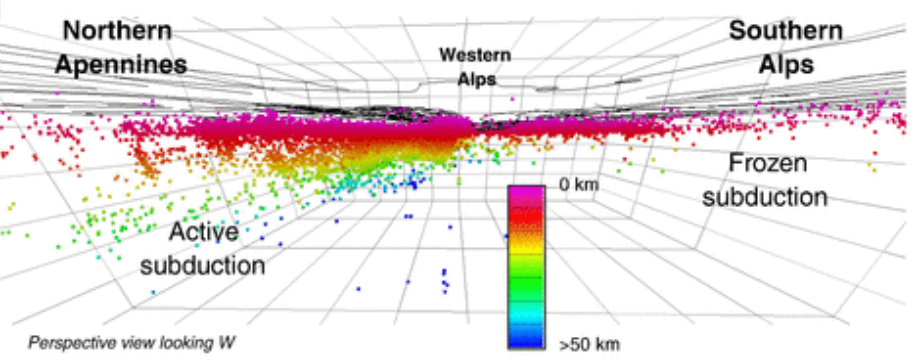

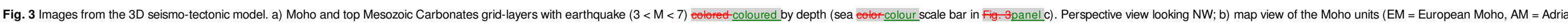

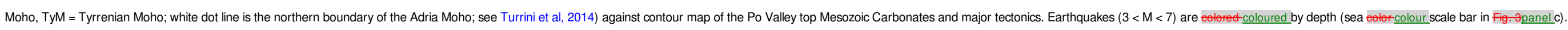

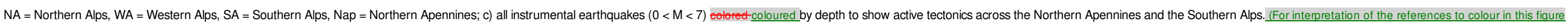
legend, the reader is referred to the web version of this article.)

In detail, inspection of the 3D model by depth rendering, contouring and perspective visualization of the tayerslayerffaulteffault grids and the earthquake events illustrates a number of observations:

1. Most of the events are concentrated at the upper-crust level, between the top basement and the top Mesozoic carbonates (Fig. 3b; red events);

2. Only a minor part of the shocks occur in the lower crust or close to the Moho interface (Fig. 3b; orange and green event)

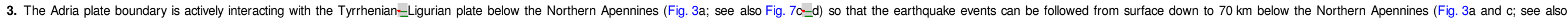
Fig. $7 \mathrm{c}=\mathrm{d}$ );

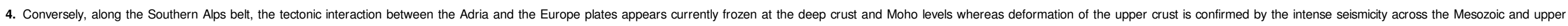
basement units (Fig. 3a and c; see also Fig. 7a-d); 


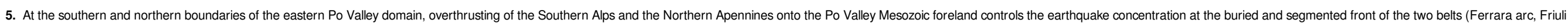
domain) (Fig. 4a);

6. Structures across the Cenozoic clastic successions and above the base-Pliocene surface (Fig. 4b) show poor instrumental seismicity (e.g. in the NW sector the Ferrara tectonic arc).
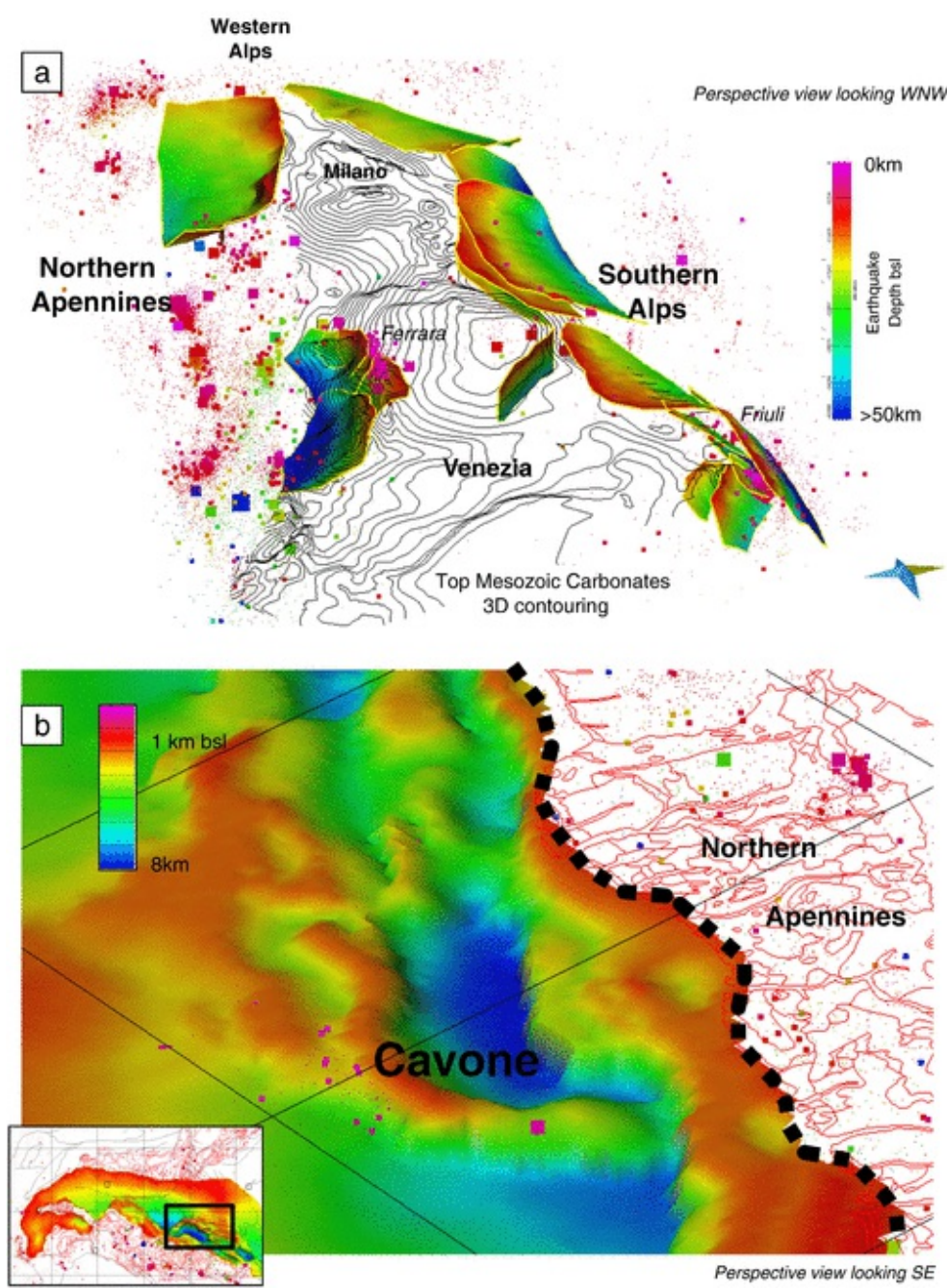

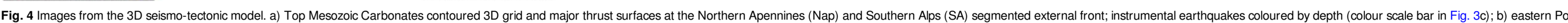

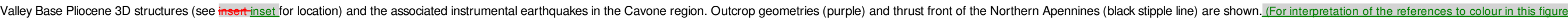
legend, the reader is referred to the web version of this article.

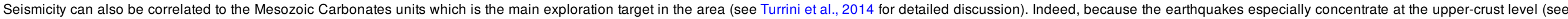

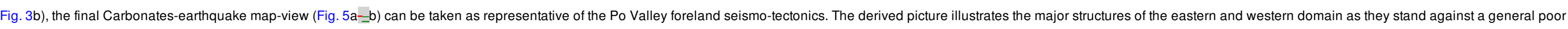
and patchy seismicity: nearly absent west of the Giudicarie lineament and rather intense although extremely localized to the east of that lineament. 


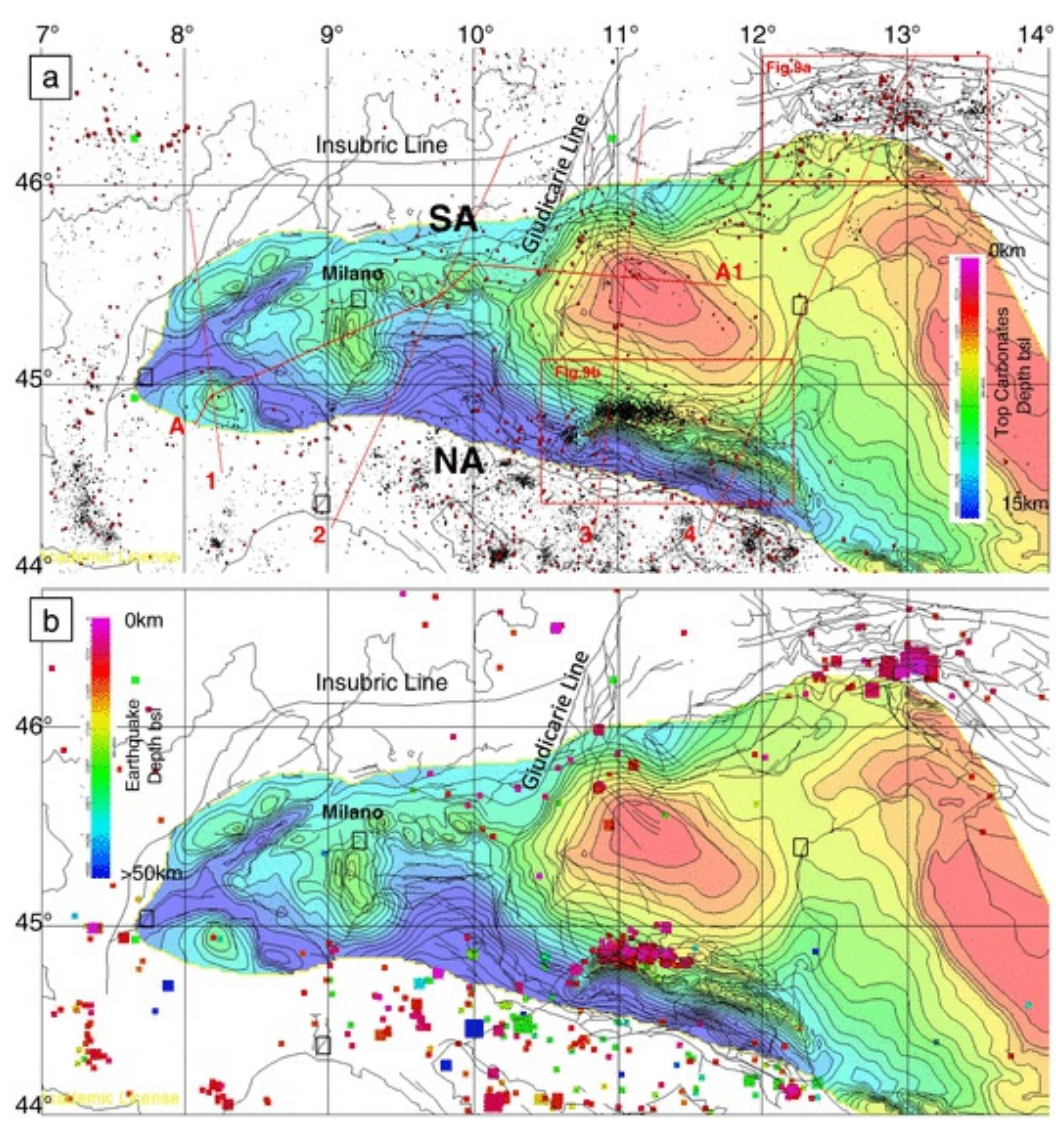

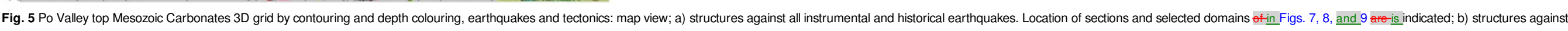
instrumental earthquakes $(4<M<7)$ coloured by depth. Horizontal net dimension is $80 \mathrm{~km}$. Latitude and longitude values are North and East of Greenwich.

\subsection{Faults and earthquakes}

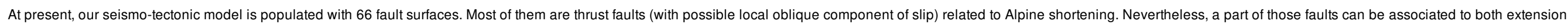
and compression that occurred through Triassic to present (Turrini et al., 2014 and all references therein). Few faults in the current 3D model are extensional faults only.

In detail, the 3D model faults can be divided into 4 groups (Fig. 6) mainly defined according to their location and depth and each characterized by specific earthquake population: 

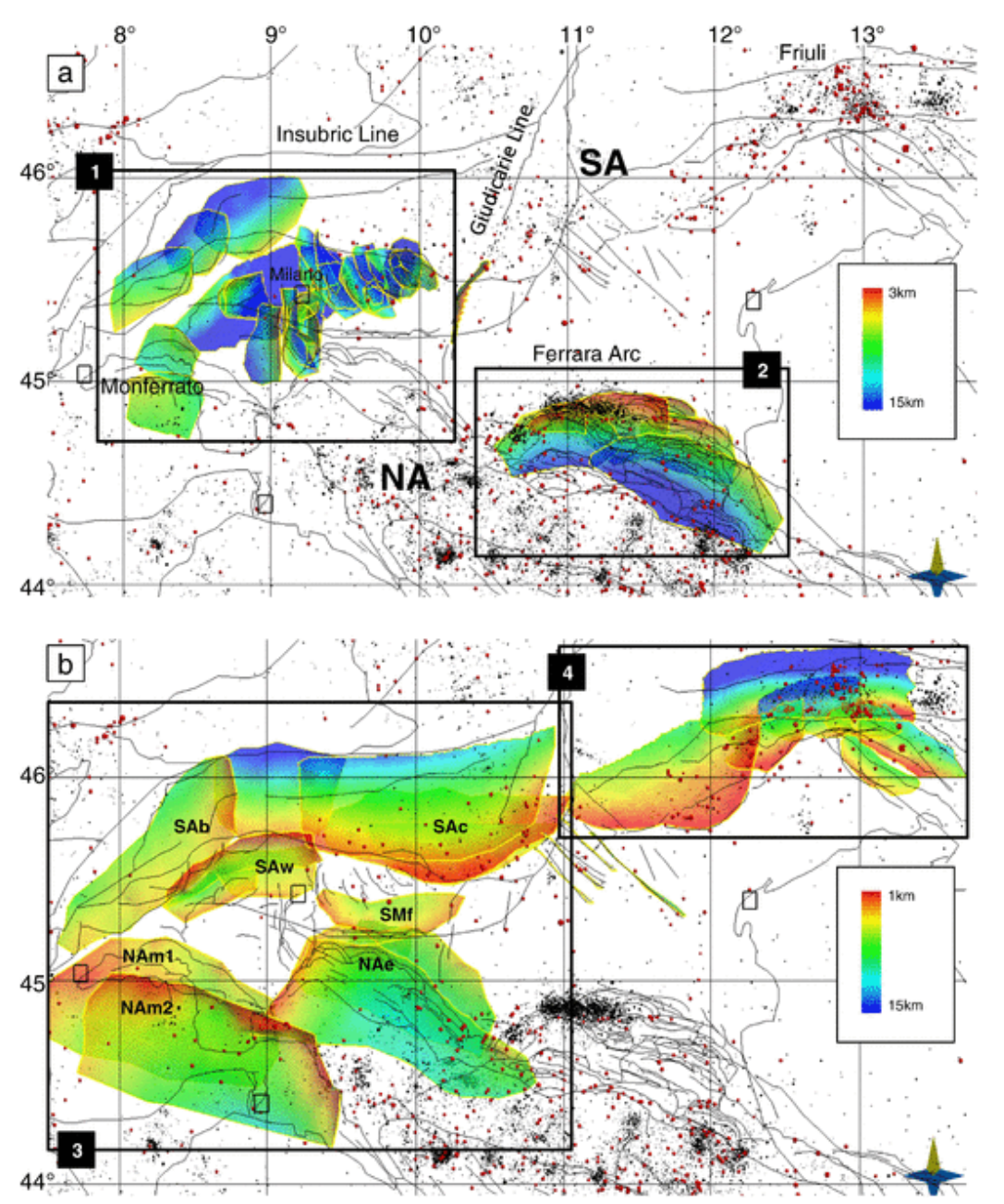

Fig. $63 \mathrm{D}$ fault surfaces, coloured by depth, against all earthquake events: see text for description of each fault-group. Horizontal net dimension is $80 \mathrm{~km}$. Latitude and longitude values are North and East of Greenwich.

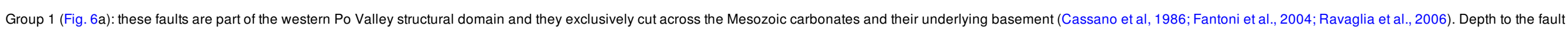

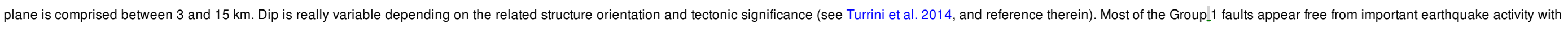
the exception of isolated faults to the east of Milan and those below the Monferrato belt (see cross-section AA1 in Fig. 8 and related discussion).

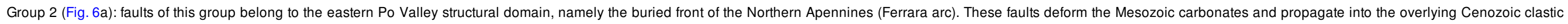

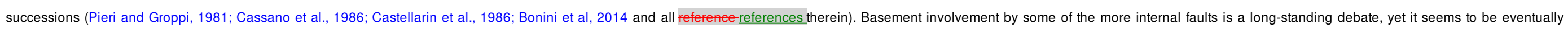

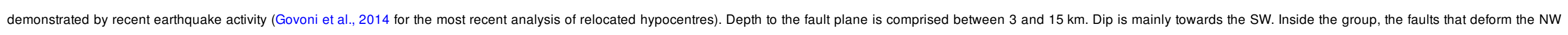

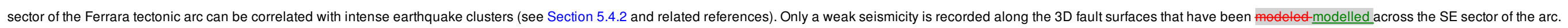

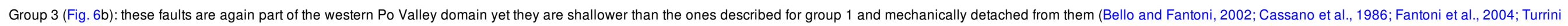
et al., 2014 and references therein). In particular they: 
3. induce thrusting of the clastic sediments at the front of the western Southern Alps (fault "SAw")

4. displace the Northern Apennine Ligurides units in the Monferrato region (fault "NAm")

5. deform the clastic succession of the Emilia and Milano buried fronts (faults "NAe" and "SMF"- respectively).

Seismicity around those faults is poor and the related magnitude values vary from low to moderate as we move from west to east, towards the Giudicarie lineament and the NW sector of the Ferrara buried arc.

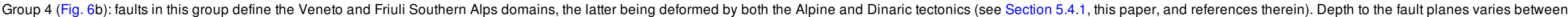
1 and $15 \mathrm{~km}$ as their dip is mostly towards the NNW (Alpine faults) and NE (Dinaric faults). Seismicity around the fault planes can be intense with high magnitude values (see Section 5.4.1).

\subsection{D model slicing and earthquakes}

Vertical slicing of the model provides further insights about the final 3D seismo-tectonic geo-volume and the methodology as well.

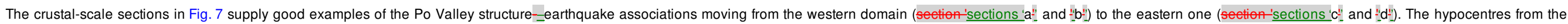

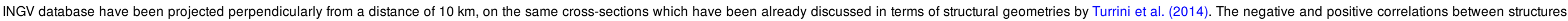

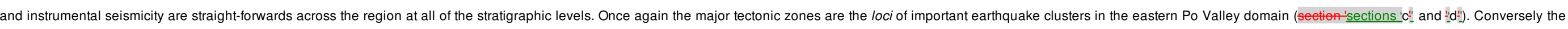

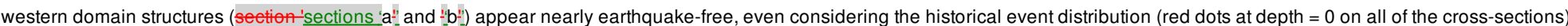



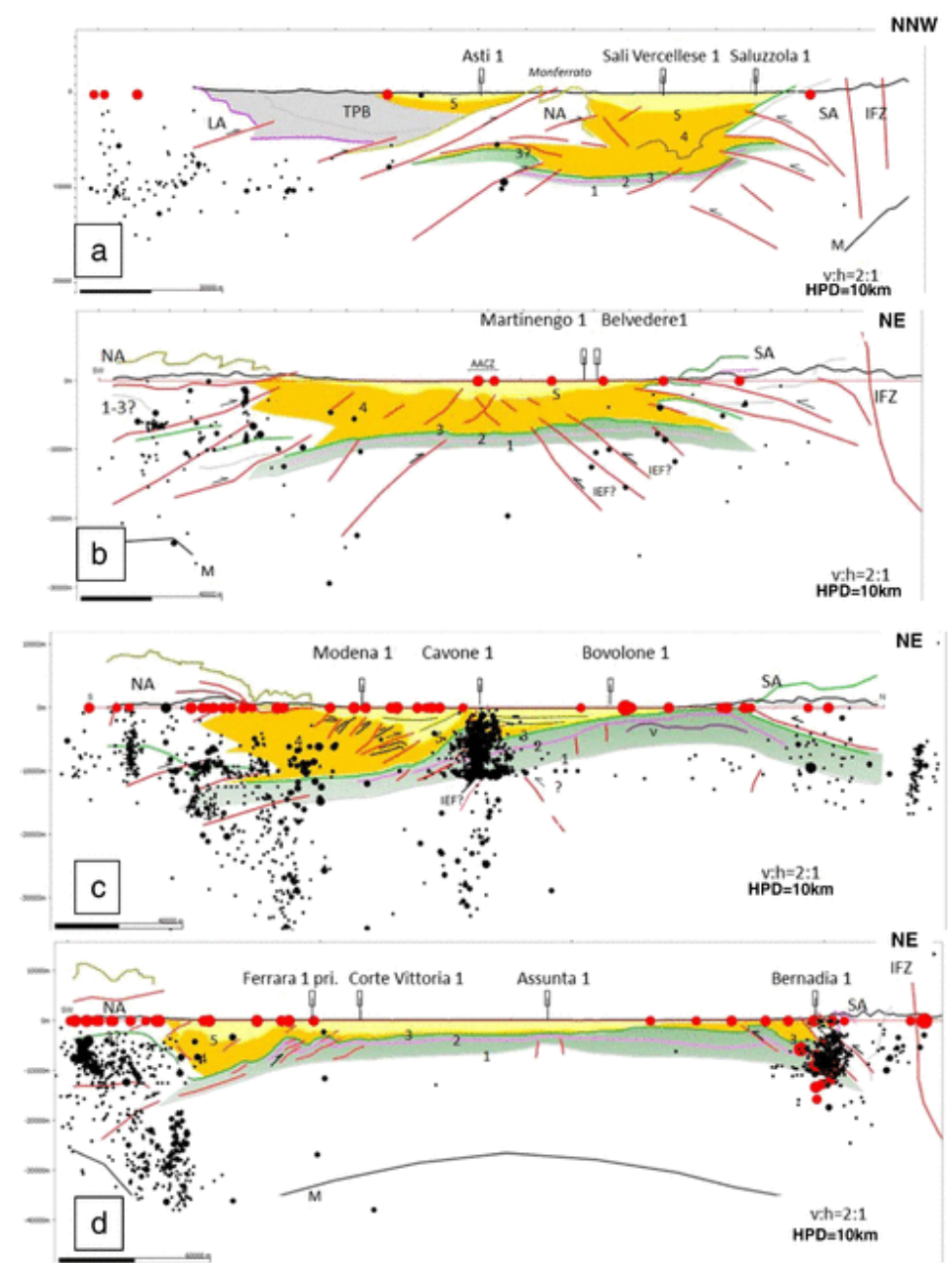

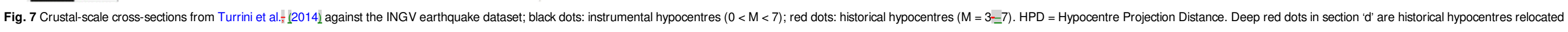

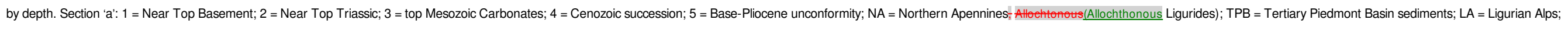

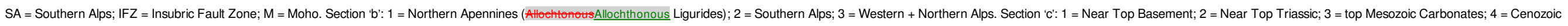

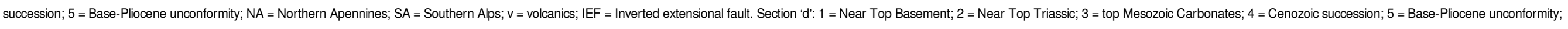
$\mathrm{NA}=$ Northern Apennines; $\mathrm{SA}=$ Southern Alps; IFZ = Insubric Fault Zone; $\mathrm{M}=$ Moho. See Fig. $5 \mathrm{a}$ for location of sections. (For interpretation of the references to colour in this figure legend, the reader is referred to the web version of this anticle.)

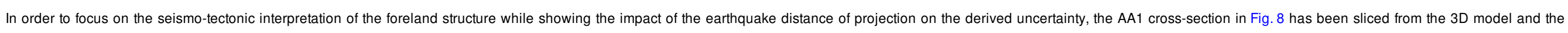
related structure_earthquake associations have been analysodanalyzed and compared to one another. 

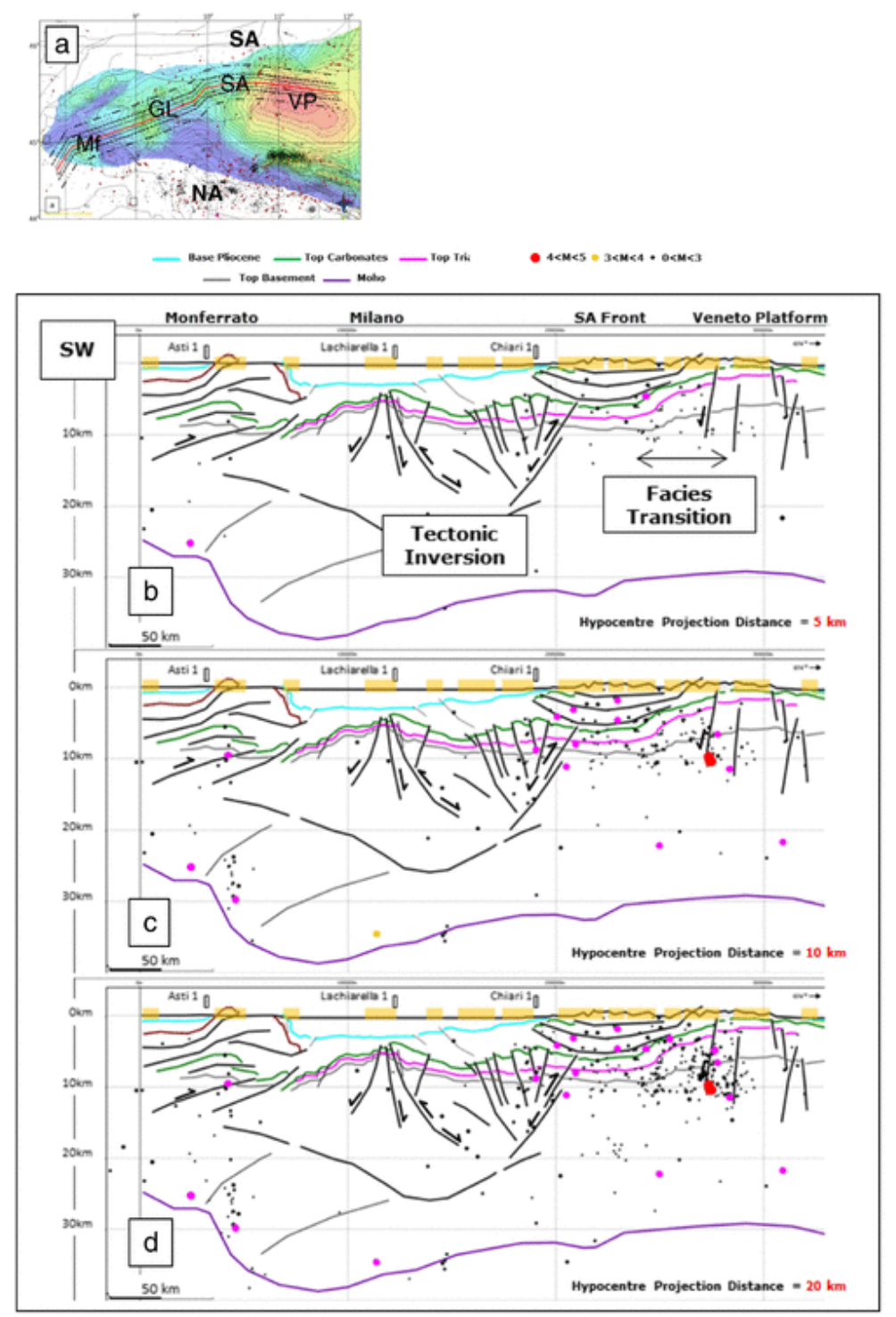

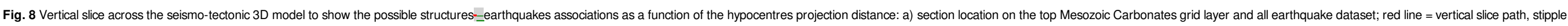

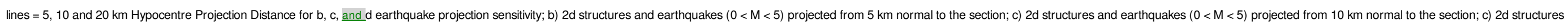
and earthquakes $(0<\mathrm{M}<5)$ projected from $20 \mathrm{~km}$ normal to the section. (For interpretation of the references to colour in this figure legend, the reader is referred to the web version of this article.)

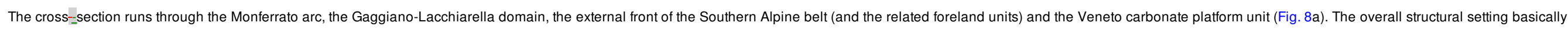

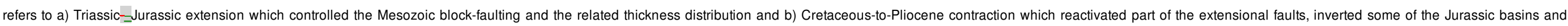
displaced the Apennines and Southern Alps towards the Po Valley foreland (Turrini et al., 2014 and all references therein).

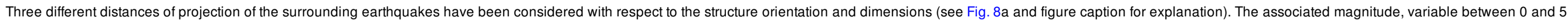




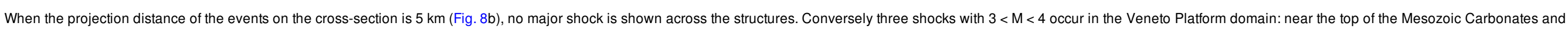

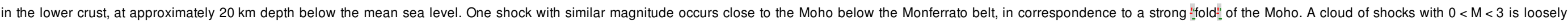

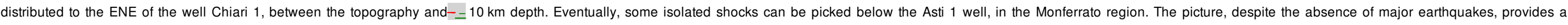
reasonable imaging of the seismo-tectonic of the area with an increasing seismicity from SW to NE.

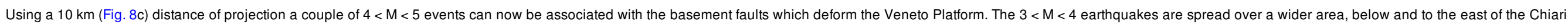

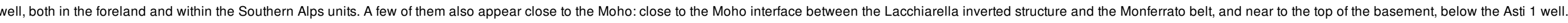

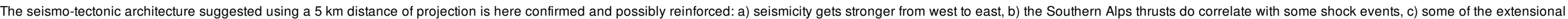
faults in the foreland can be correlated to isolated shocks (Chiari basin) and some other are nearly shock-free (Lacchiarella basin), and d) there seems to exist a seismogenic layer above the Moho interface.

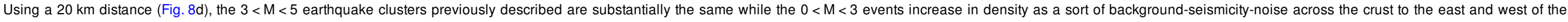
Gaggiano-_Lacchiarella zone

From the performed analysis we conclude that:

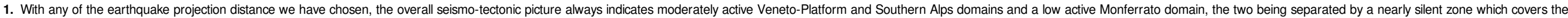
Gaggiano=_Lacchiarella structural domain_

2. Along the selected cross-section path, increase in the projection distance from 5 to $20 \mathrm{~km}$ results to an increase of the structure seismicity for all of the domains with no visible inconsistency among the different tests.

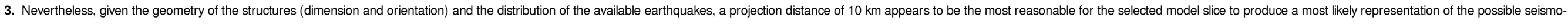

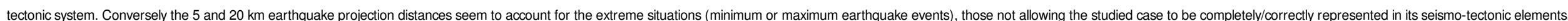

\subsection{Seismo-tectonics of selected structural domains around the Po Valley basin}

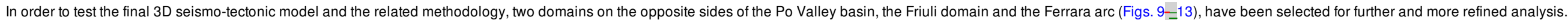




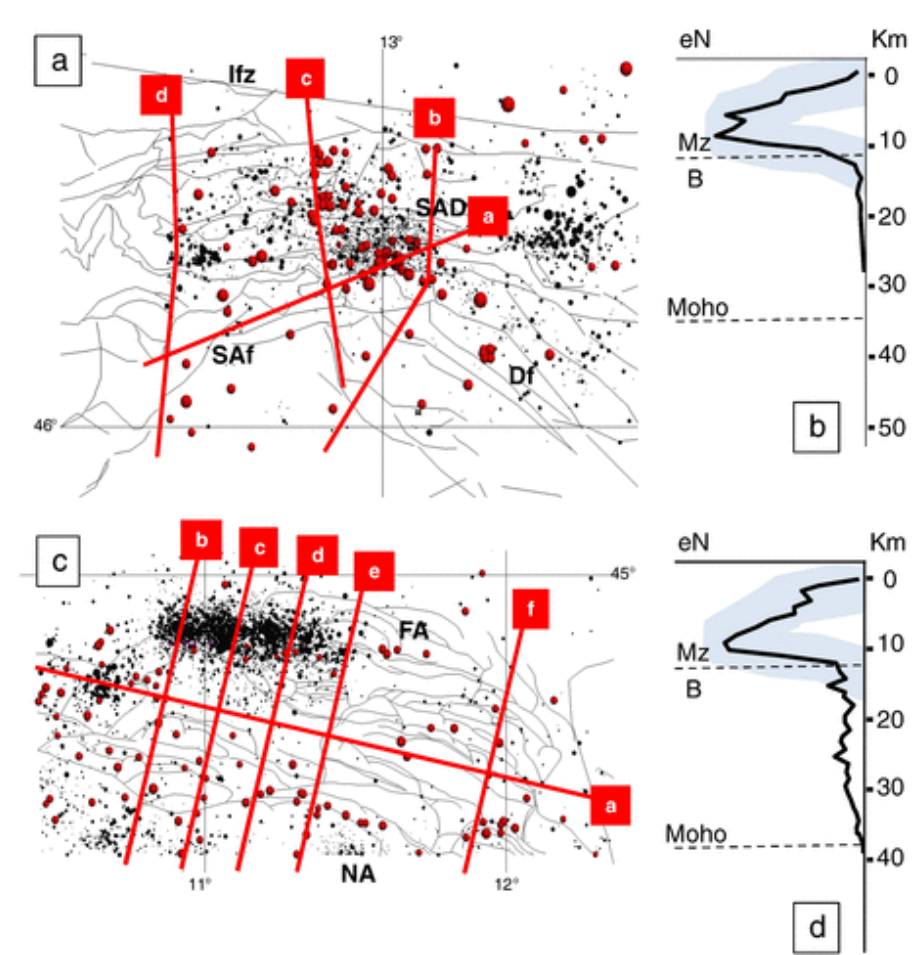

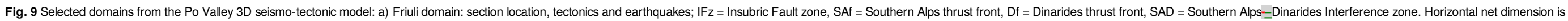

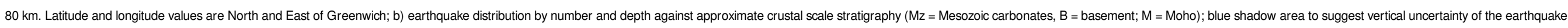

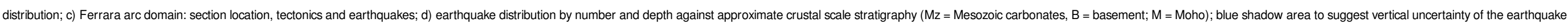
distribution. (For interpretation of the references to colour in this figure legend, the reader is referred to the web version of this article.) 


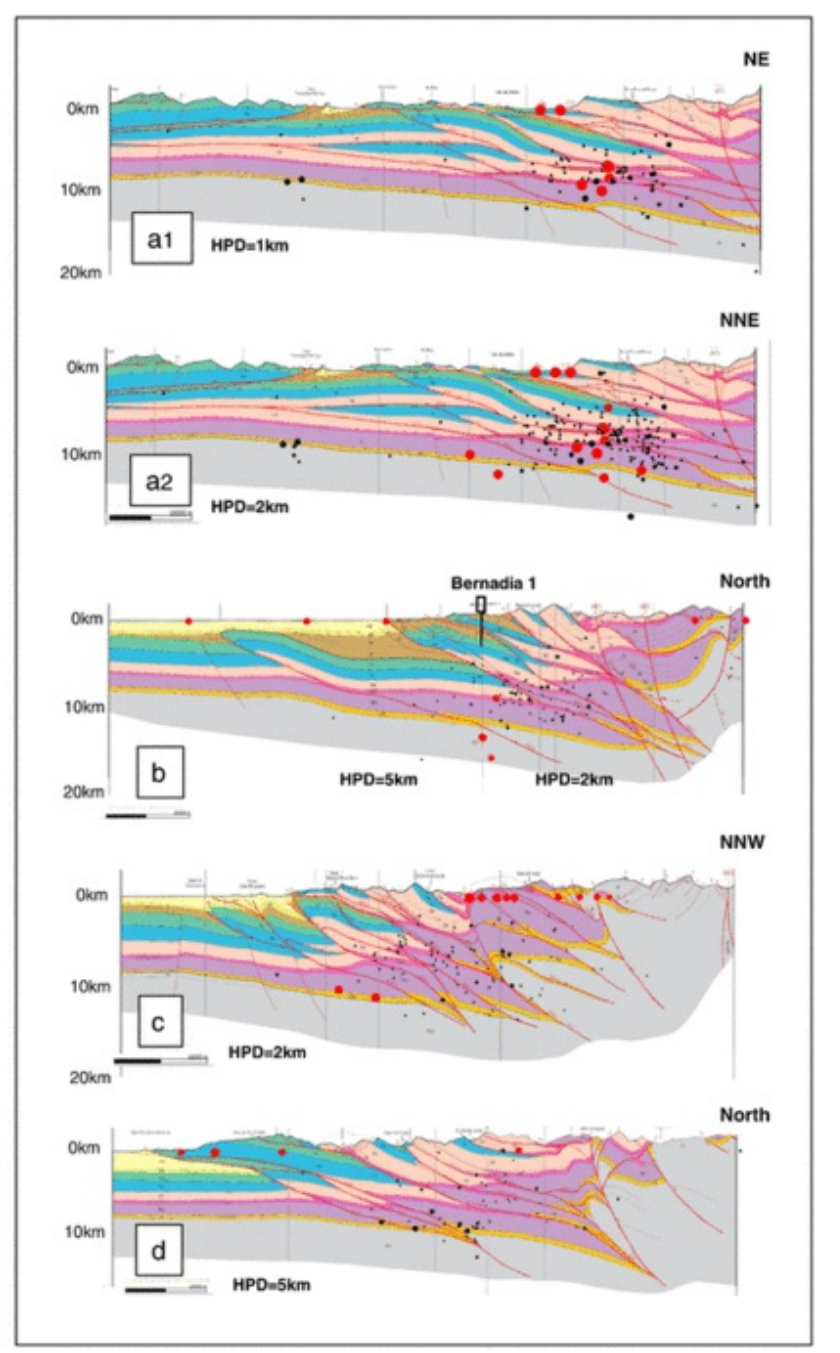

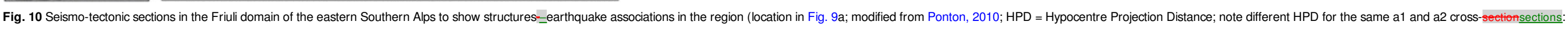
see text for discussion). Deep red dots are relocated 


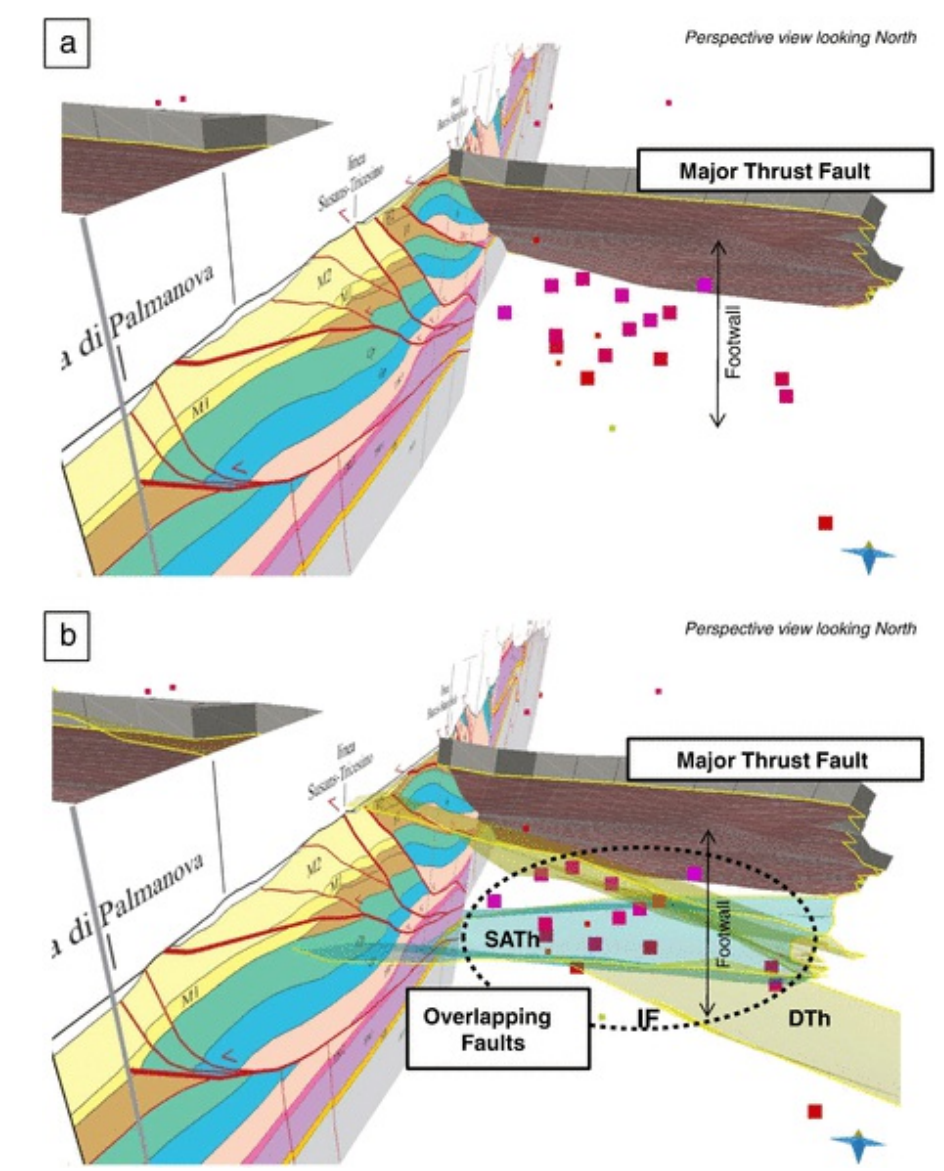

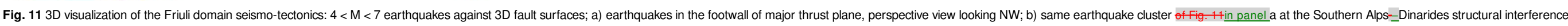
(IF = interference zone; SATh = Southern Alps thrust; DTh = Dinaric thrust:- see text for discussion). Perspective view looking NW. 


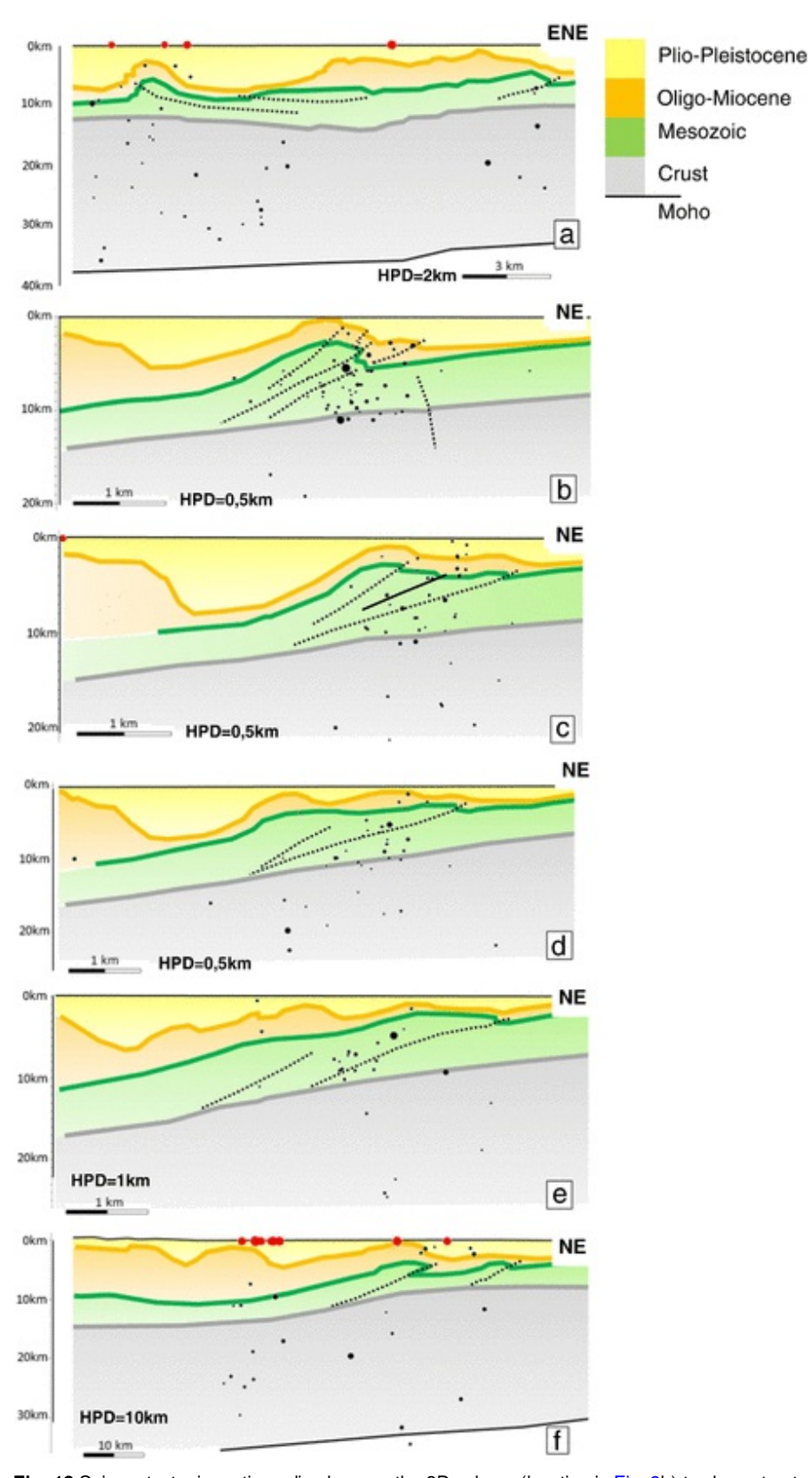

Fig. 12 Seismo-tectonic sections sliced across the 3D volume (location in Fig. 9b) to show structure--earthquake association across the Ferrara tectonic arc; HPD = Hypocentre Projection Distance; see text for discussion. 

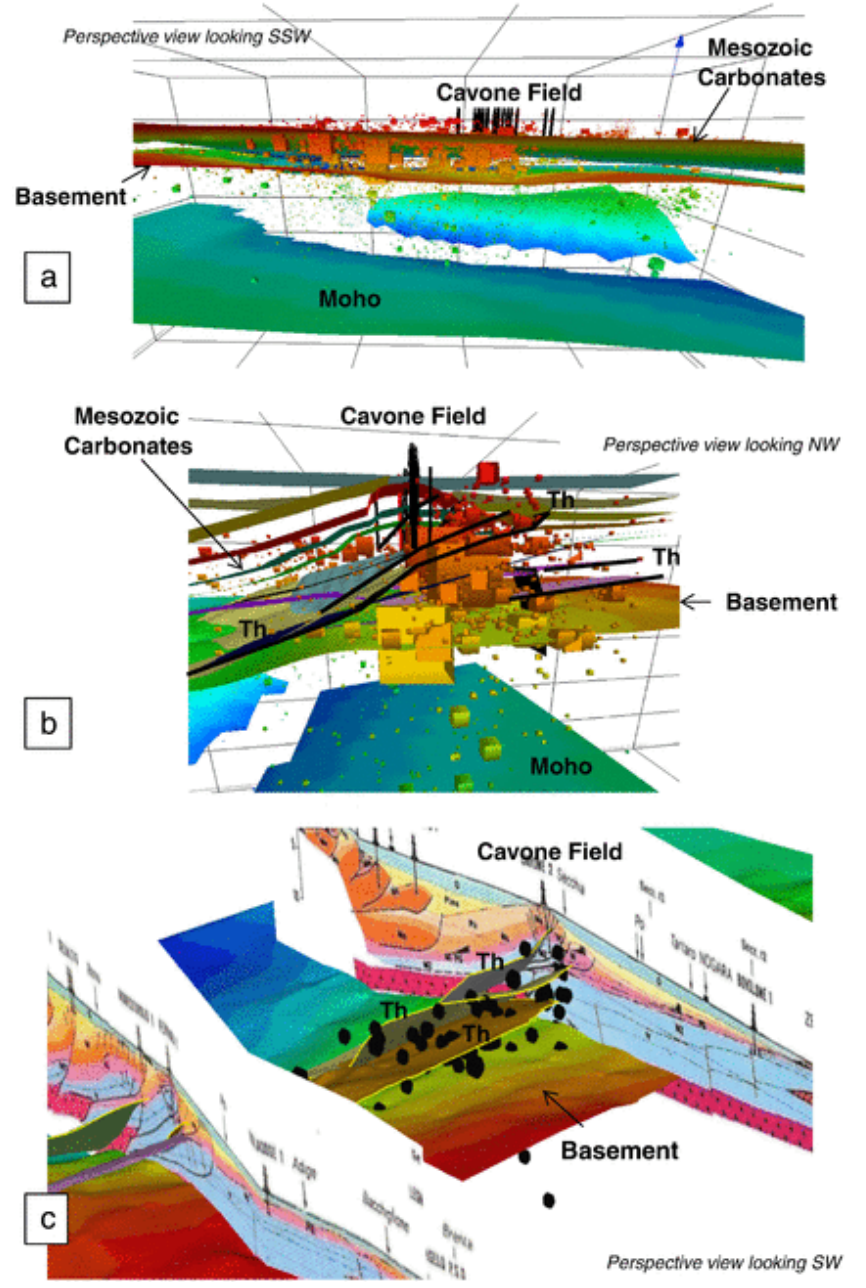

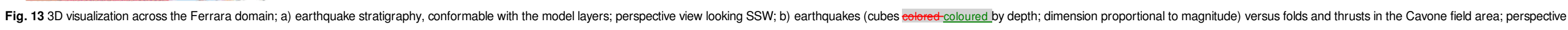
view looking NW. c) transfer zone, overlapping thrusts and earthquake distribution between the Cavone field and the Ferrara anticline (cross sections from Cassano et al., 1986). Perspective view looking SW; see text for discussion.

\subsubsection{The Friuli domain}

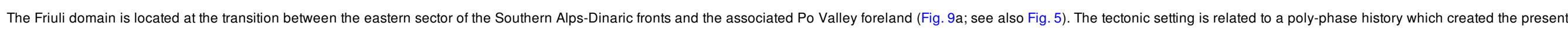

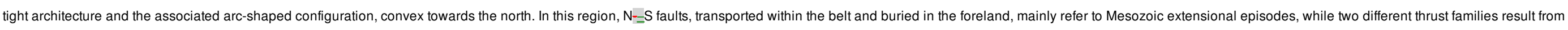

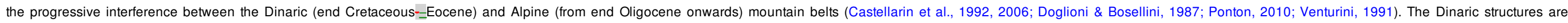

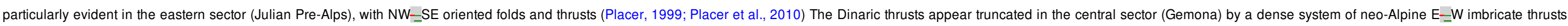

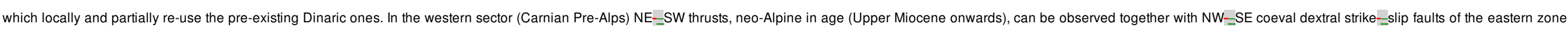

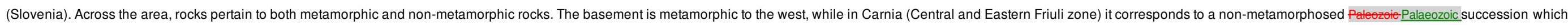

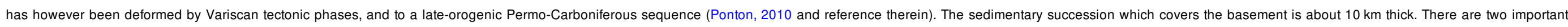

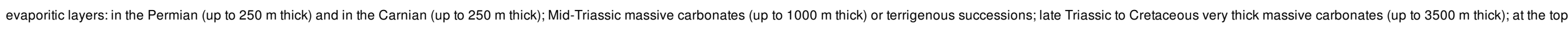




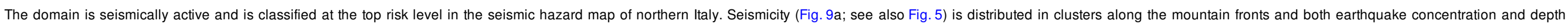

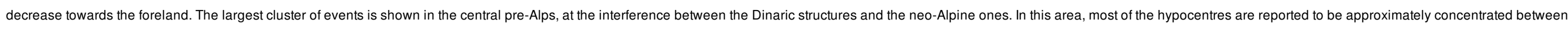

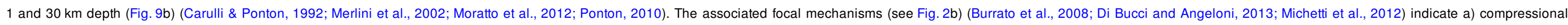

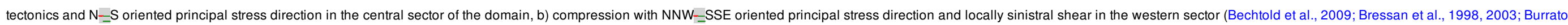

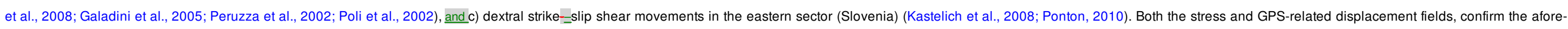
mentioned tectonics and the present kinematics (see also Serpelloni et al., 2005, 2012, 2013; Bechtold et al., 2009; Devoti et al., 2011; Michetti et al., 2012).

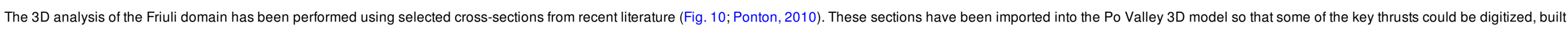

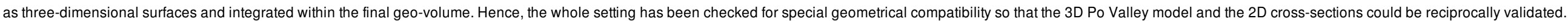

Noteworthy, within this domain, some of the historical hypocentres have been relocated by the INGV specialists and their depth has been assigned (deep red dots in sections 'a-d' of Fig. 10).

Section $a_{-}^{-1}$

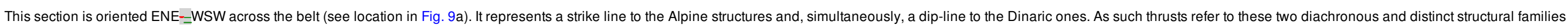

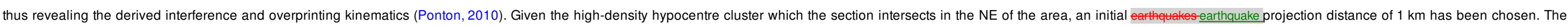

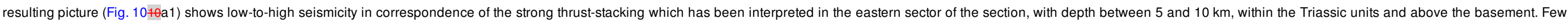

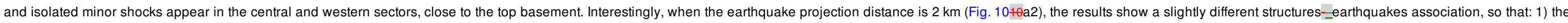

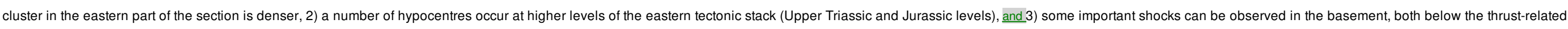
imbricates and in the central part of the section.

Section ${ }^{-1}$

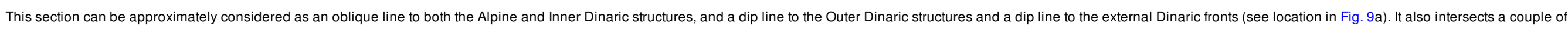

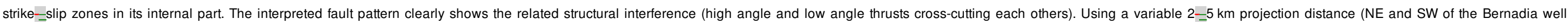

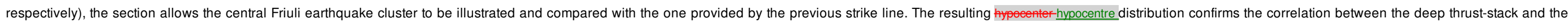

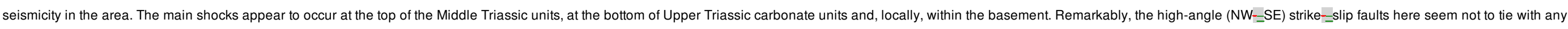
earthquakes, yet their SE segments are highly seismogenic (Burrato et al., 2008; Ponton, 2010).

Sections 'c' and 'd'

Both the sections are dip-lines with respect to the Alpine structures and cut through the entire Alpine belt (see location in Fig. 9a). The earthquake projection distance is $2 \mathrm{~km}$ for section $\mathrm{c}$ and 5 for section $\mathrm{d}$.

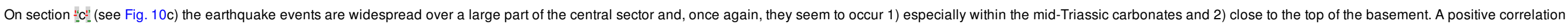
among the projected shocks and the interpreted thrusts is really evident at the footwall of the basement units.

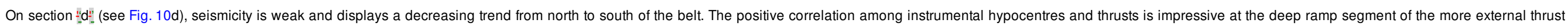
surface. The outer and shallow thrust-anticline can be likely associated with the historical shocks (i.e. $0 \mathrm{~m}$ depth).

\section{$3 D$ visualization}

The seismo-tectonic pattern of the region is outstanding when observed in the 3D volume (Fig. 11). In particular, the anatomical analysis of the model confirms that the central Friuli high-density earthquake cluster:

1. is localized in the footwall of a major thrust zone whose footwall volume has been imbricated by the recent active tectonic (Fig. 11a) 
2. is related to the interference between Alpine and Dinaric structures and the derived overlapping thrust surfaces (Fig. 11b) those being locally active during the "same" geological interval (ie. the Aps and the Dinarides are active belts at present).

\subsubsection{The Ferrara domain}

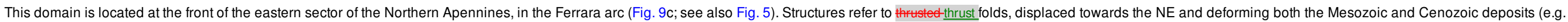

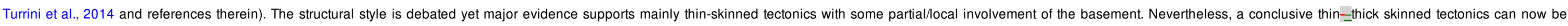

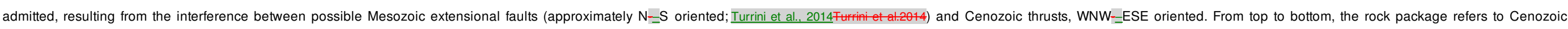

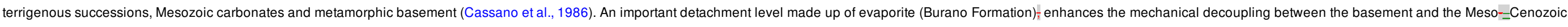

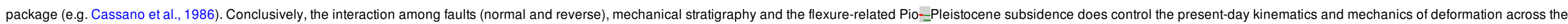
entire domain.

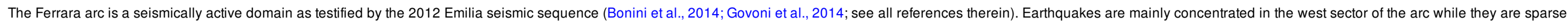

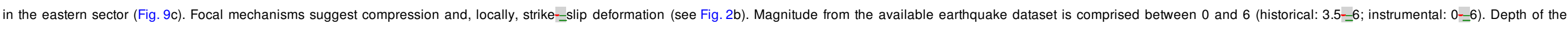

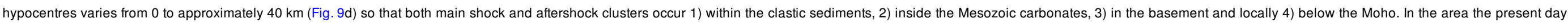

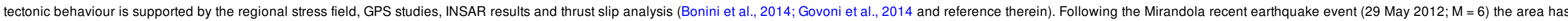

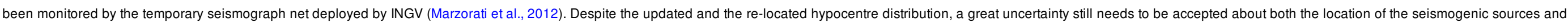
the related thrust plane geometry.

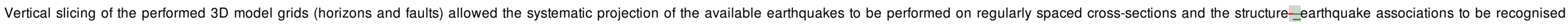
(Fig. 12).

Section 'a'

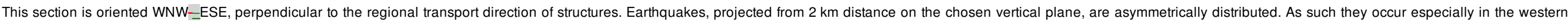

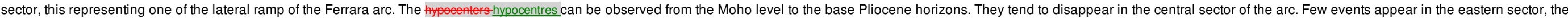
eastern lateral ramp domain of the Ferrara arc. On this cross-section no particular correlation can be defined between earthquakes and the faults sliced from the 3D model.

Sections:b- to-t:

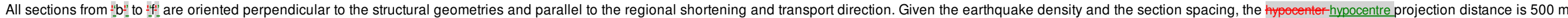

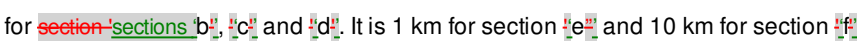

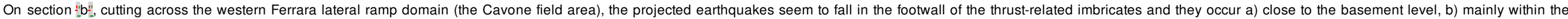
Mesozoic carbonate layers and c) subordinately inside the Oligo-_Miocene layers. The shallower main shock and some of the minor events can be correlated with the 3D model thrusts.

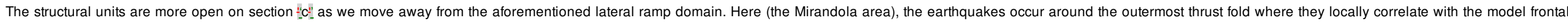

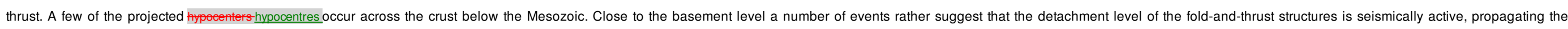
deformation towards the $\mathrm{NE}$

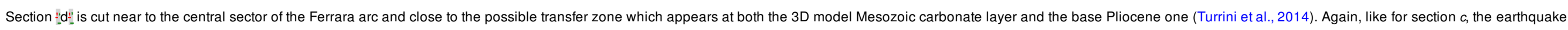

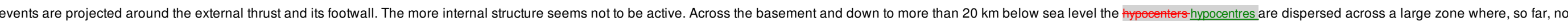
major faults have been modetedmodelled inside the 3D seismo-tectonic volume.

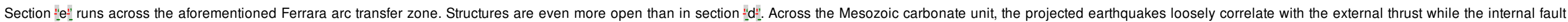

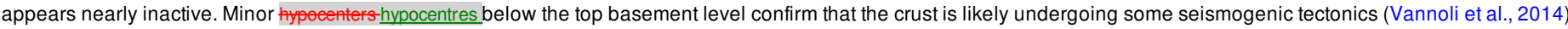




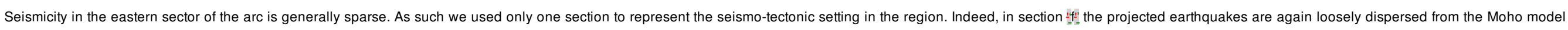

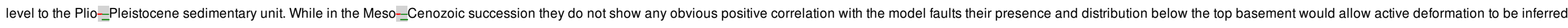
at great depth in the crust (Vannoli et al., 2014).

$3 D$ visualization

3D visualization of the Ferrara arc units can better show the complex seismo-tectonics across the region. The selected perspective views (Fig. 13)

1. confirm a possible layering of the seismicity a) close to the top basement, b) within the Mesozoic carbonate unit and c) above the base Pliocene layers of the model (Fig. 13a)

2. allow partitioning of the shocks to be observed across the faulted structures, apparently in the footwall of the major faults (Fig. 13b)

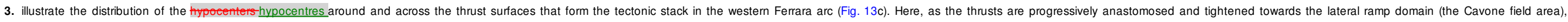
deformation and the associated earthquakes are transferred across the different, overlapping thrusts and the intervening rely-zones.

\section{Discussion}

\subsection{Methodology}

The first point which obviously needs to be discussed is the methodology so far used to build and analyze the performed Po Valley 3D seismo-tectonic model.

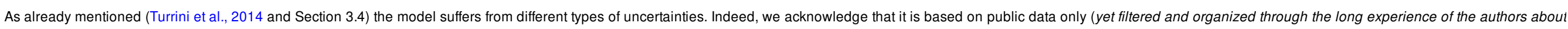

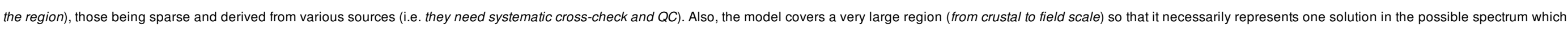
could be derived from the chosen model building workflow. Conclusively, errors may refer to both structure building/interpretation and earthquake parameters (magnitude, vertical and horizontal location).

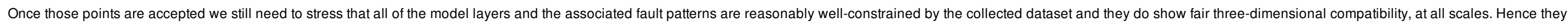

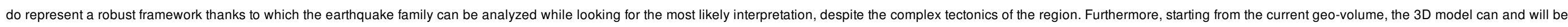

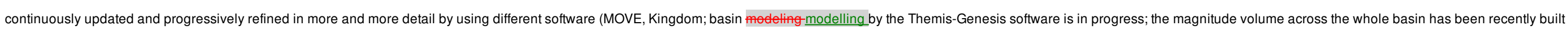
using the GOCAD software-_-Turrini et al., 2015).

In terms of specific earthquakes_-_structures integration and analysis, let us have a look at the major improvements that the performed model provides with respect to the past results.

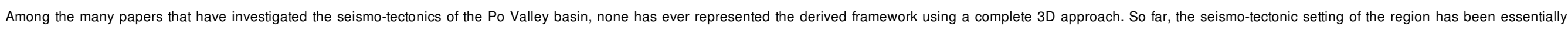

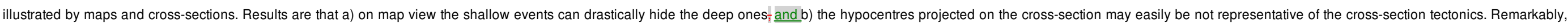

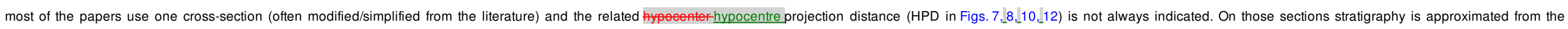

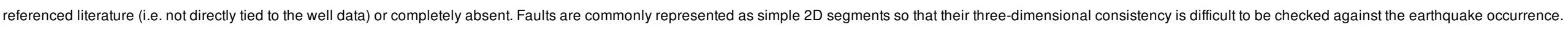

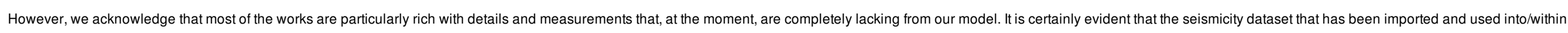

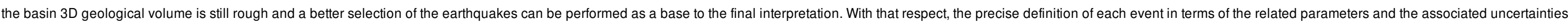

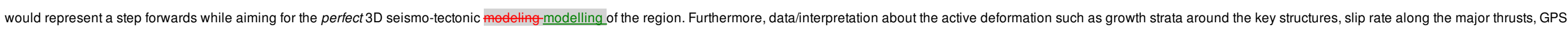
analysis, focal mechanisms and geomorphological indicators (see references in Section 2 of this paper) could definitely bring to the 3D model immense benefit and improvement.

This might be the road ahead for future development and improvement of the model.

\subsection{Po Valley 3D seismo-tectonics}

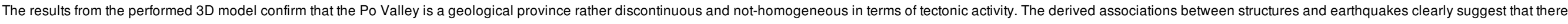

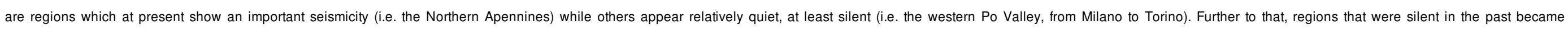




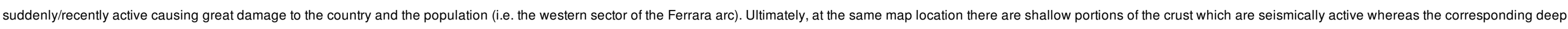
levels appear seismically frozen (i.e. the Friuli area).

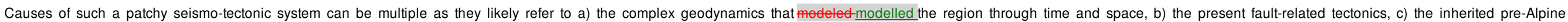
paloogeography palaeogeography and d) the region earthquake-mechanical stratigraphy.

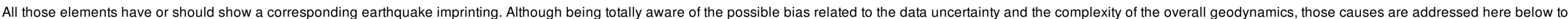
raise questions and discussion

\subsubsection{Earthquakes versus Po Valley geodynamics}

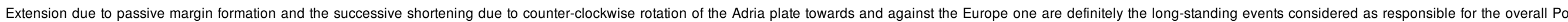

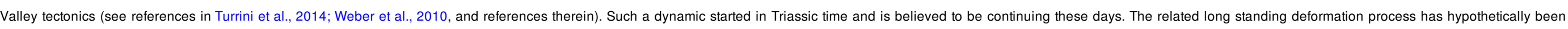

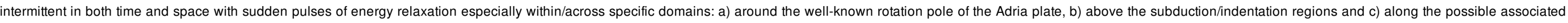
transverse zones.

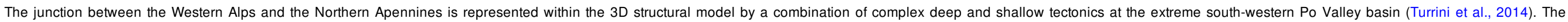

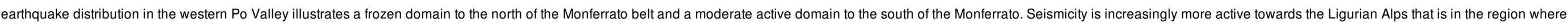
the possible pole of rotation for the Adria/Po Valley plate motion is inferred (Vignaroli et al., 2008).

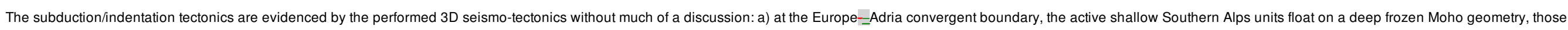

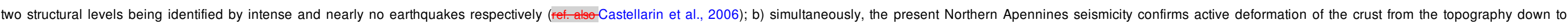

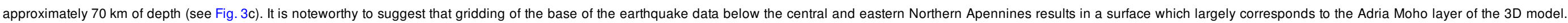

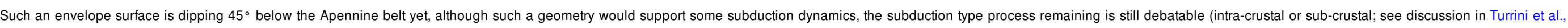
2014).

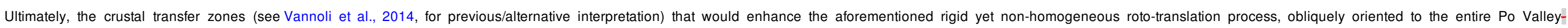

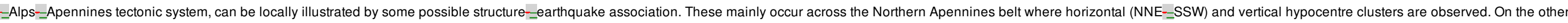

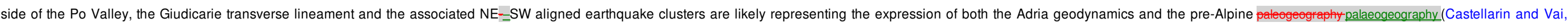
1982)

\subsubsection{Earthquakes versus Po Valley faults}

Provided that better knowledge about the faults of a region means better understanding of their seismogenic potential, the faults-_earthquakes issue is likely the most important from the performed 3D seismo-tectonic model.

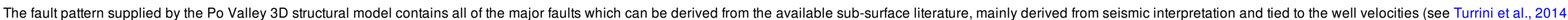
for dataset references). As such, they should suggest reliable geometries which actively concur to define the basin tectonic architecture yet they do not necessarily suggest any active seismogenic discontinuity.

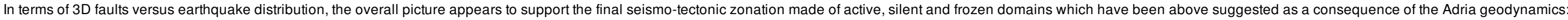

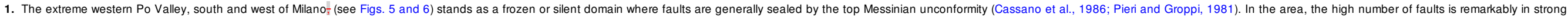
contrast with the apparent lack of important recent seismicity (see Figs. 5 and 6);

2. the western Po Valley domain east of Milan is a relatively active domain with low-to-moderate seismicity localized along selected faults (see Fig. 8 and text for discussion);

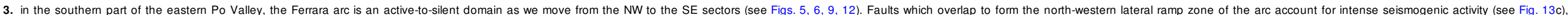
whereas the eastern sector faults are only expressed by very local/sparse seismicity; 


\subsection{Earthquakes and paleogeographical-palaeogeographical framework}

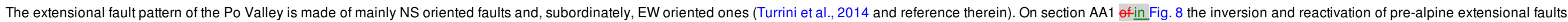

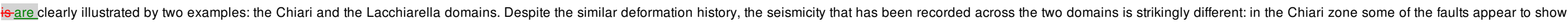

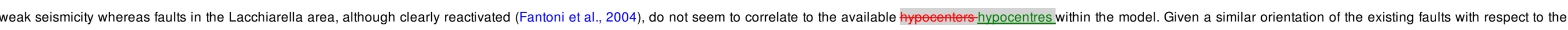

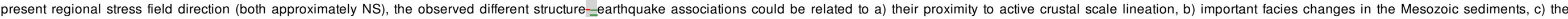

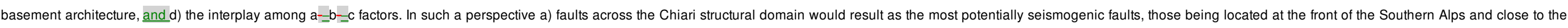

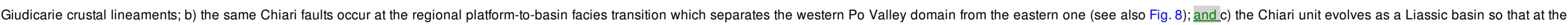
end of Mesozoic it defines the footwall (low-basement feature) to the Veneto basement high (see also Fig. 8).

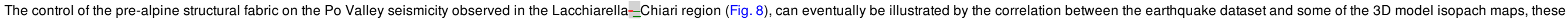
already presented and discussed in Turrini et al. (2014).

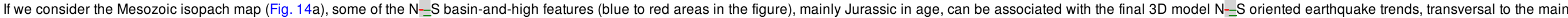
NE-_SW and NW-_SE oriented ones. Among them the most prominent earthquake paleo_palaeo-structure association is definitely the Giudicarie one.

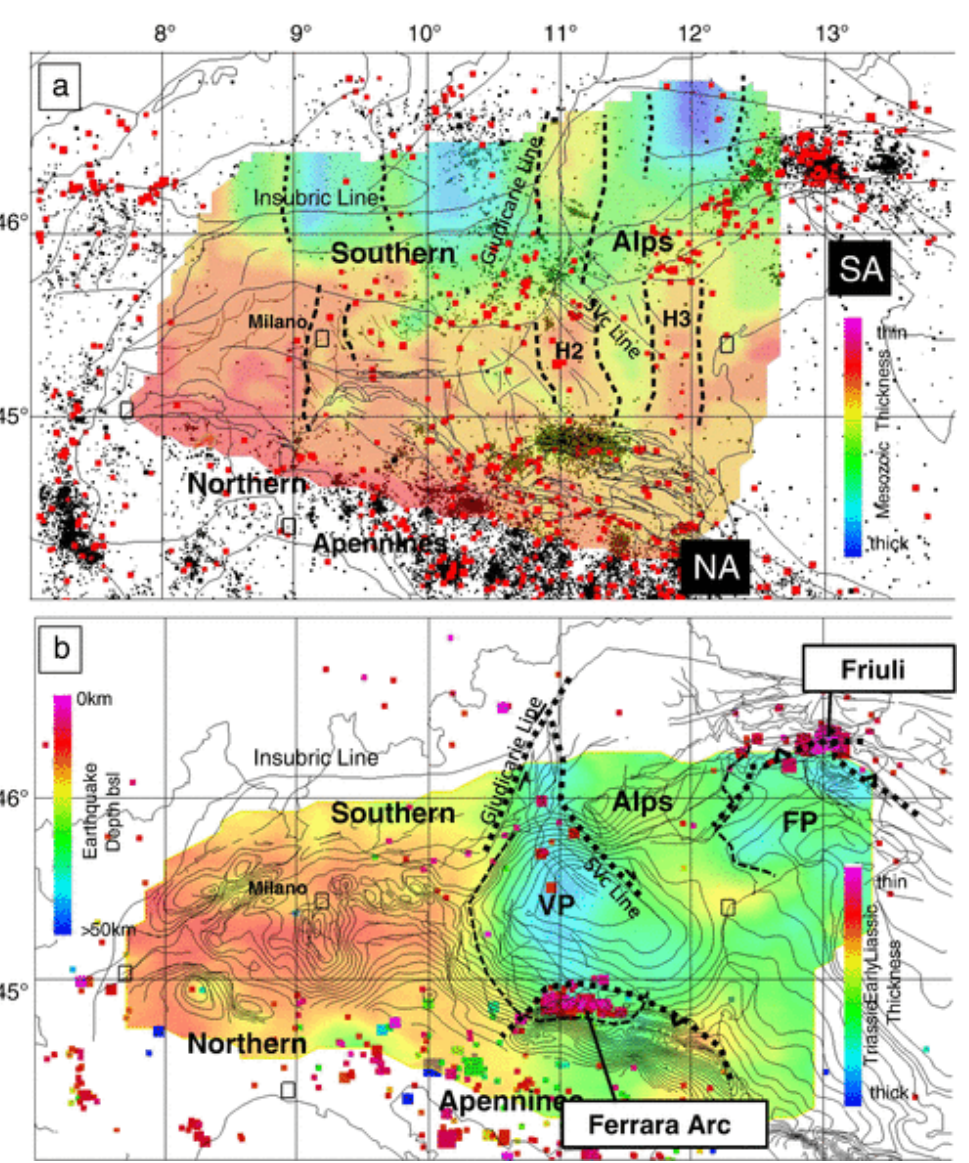




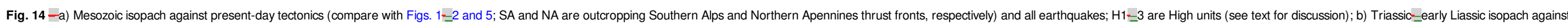
major earthquakes (4-7 magnitude): $\mathrm{VP}=$ Veneto platform carbonate domain, $\mathrm{FP}=$ Friuli platform carbonate domain (see text for discussion).

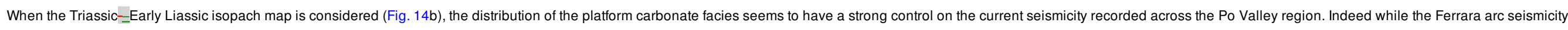
appears to happen at the southern margin of the Veneto Platform, earthquakes in the Friuli region are clearly distributed along the Friuli Platform margin (Ponton, 2010).

\subsection{Earthquakes and mechanical stratigraphy}

Results from the performed seismo-tectonic model suggest a crustal-scale earthquakes stratigraphy (Fig. 15a) which, together with the regional mechanical stratigraphy (Fig. 15b), would control the final Po Valley structural style.
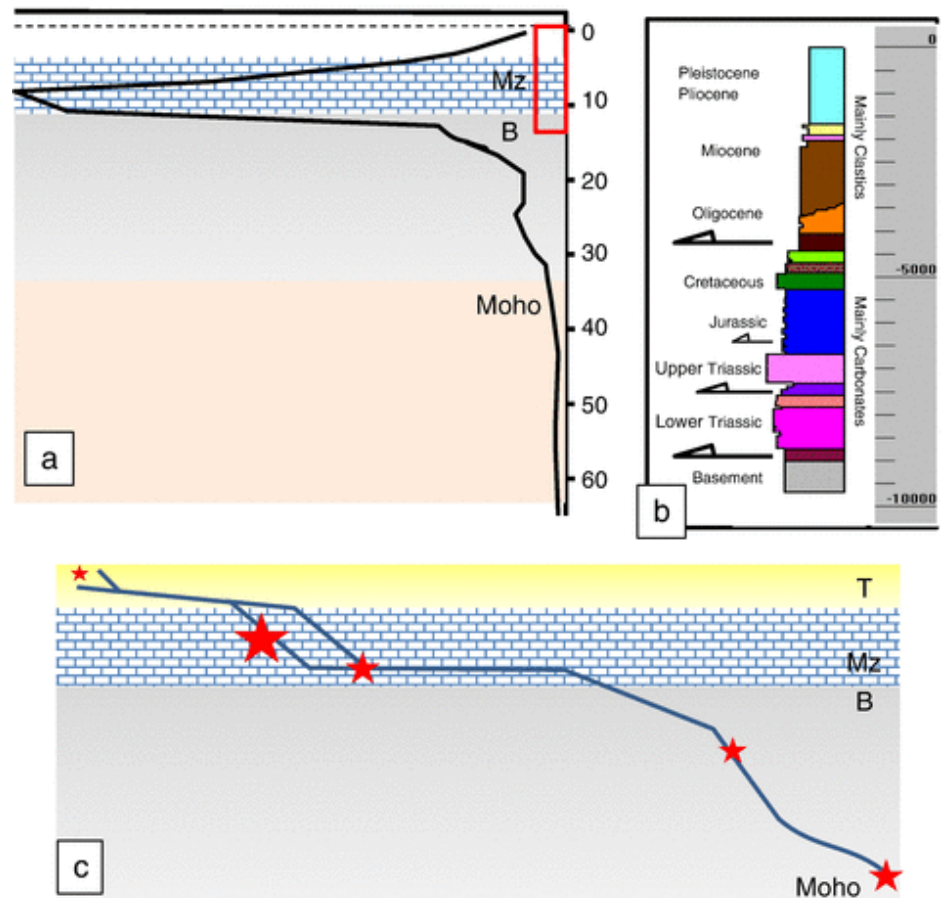

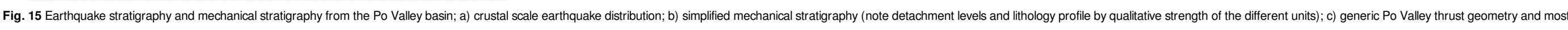
likely earthquake shocks derived from this study (dimension of red star by earthquake magnitude). (For interpretation of the references to colour in this figure legend, the reader is referred to the web version of this article.)

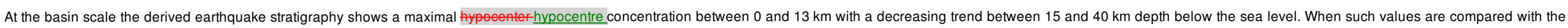

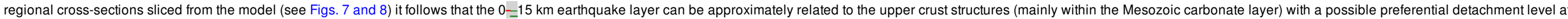

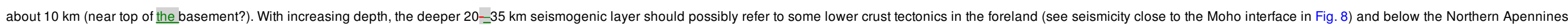
belt (see Fig. 3b and c).

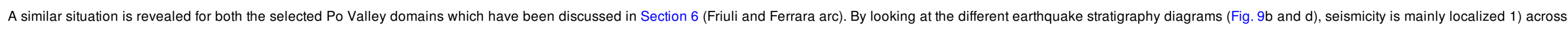
the competent Mesozoic carbonates, 2) close to the top of the basement and subordinately 3) within the upper crust.

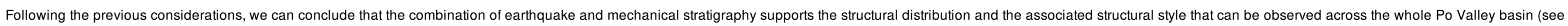
discussion in Turrini et al., 2014). Indeed a thick-_thin skinned tectonics likely fits the described earthquake-layering, so that a Po Valley seismogenic thrust surface (Fig. 15c) would progressively develop as followfollows: 
3. flatten near the top basement interface

4. ramp again across the carbonates

5. flatten at the base of the Tertiary succession

6. ramp across the Mio-_Pliocene sediments.

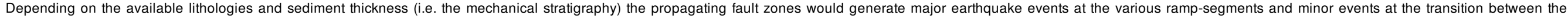
basement and the Mesozoic layer (Figs. 15c and 16). Seismicity may also eccurs-occur along the flat-segments yet eventually be reduced

1. at the Upper-Triassic level, (i.e. the Burano evaporites, a major detachment in the Apennines)

2. at the base of the Tertiary clastic successions where fluid overpressures are reported (Bosica and Shiner, 2013) and likely to be expected nearly all through the Po Valley basin.

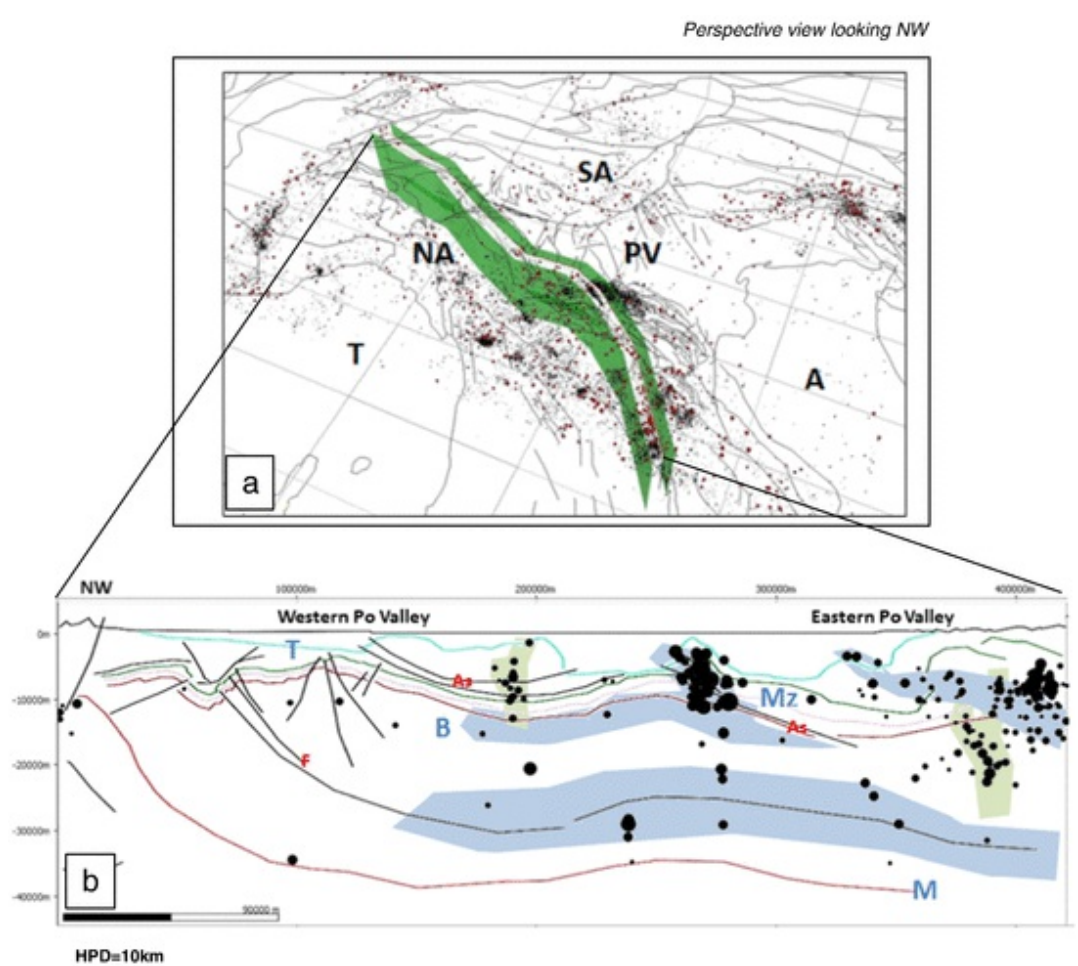

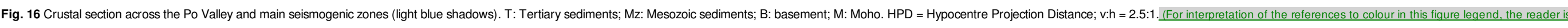
referred to the web version of this article.)

Eventually, given the described paleopalaeo-tectonics (see Fig. 14) the fault zone geometry may deviate in both the horizontal and vertical direetiondirections.

\section{Conclusions}




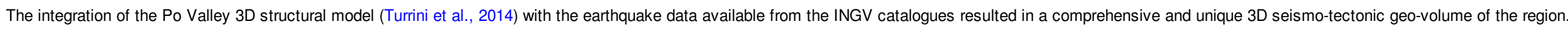

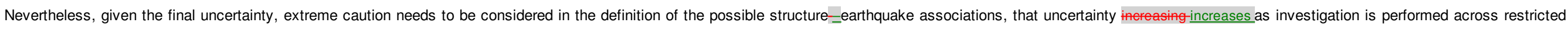
structural domains.

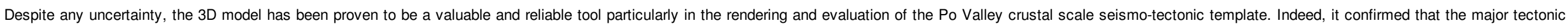

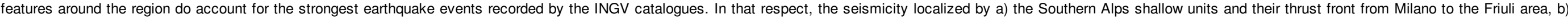

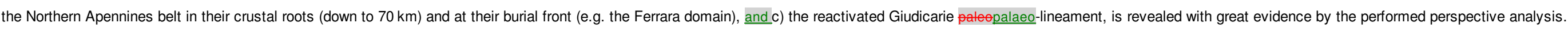

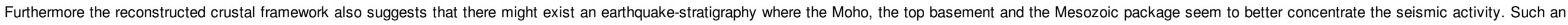
earthquake stratigraphy works with the well-known Po Valley mechanical stratigraphy to develop the final variable structural style.

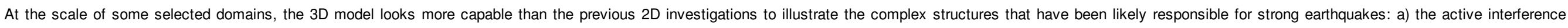

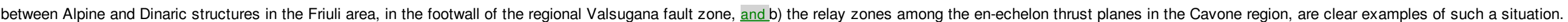

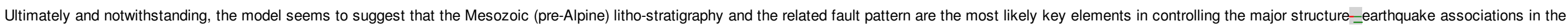

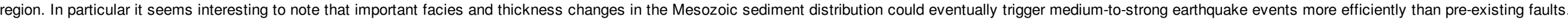

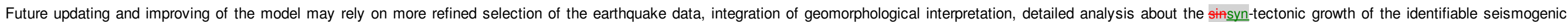
structures, and new software applications for an alternative elaboration of the earthquake dataset.

\section{Uncited reference}

Maesano and The Italian Geomol Team, 2014

\section{AcknowledgmentsAcknowledgements}

Giovanni Toscani, Peter Shiner, two anonymous reviewers and, in particular, Pierfrancesco Burrato are kindly acknowledged for reviewing and actively concurring to the improventimprovement of this paper.

\section{References}

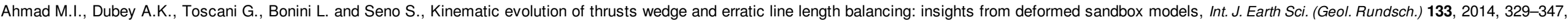

http://dx.doi.org/10.1007/s00531-013-0947-8.

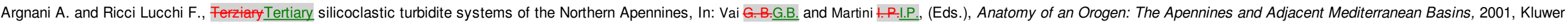
Academic Publishers, 327-350.

Barba S., Finocchio D., Sikdar E. and Burrato P., Modelling the interseismic deformation of a thrust system: seismogenic potential of the Southern Alps, Terra Nova 2013 , http://dx.doi.org/10.1111/ter.12026.

Bartolini C., Caputo R. and Pieri M., Pliocene--Quaternary sedimentation in the Northern Apennine Foredeep and related denudation, Geol. Mag. 133, 1996, 255-273, http://dx.doi.org/10.1017/S0016756800009006.

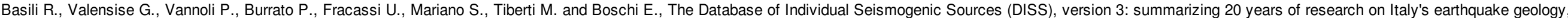
Tectonophysics 453, 2008, 20-24.

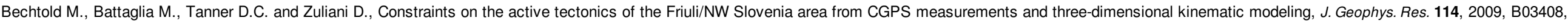

http://dx.doi.org/10.1029/2008JB005638

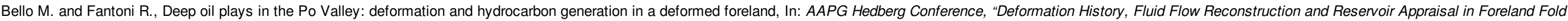
and Thrust Belts" May 14_18, Abstract Book, 1__4, 2002, (http://www.searchanddiscovery.com/documents/2003/bello/images/bello.pdf).

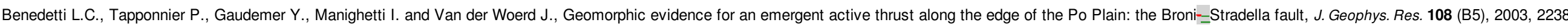


http://dx.doi.org/10.1029/2001JB001546.

Berg R.C., Russell H. and Thorleifson L.H., (Eds.), Three-dimensional Geological Mapping for Groundwater Applications__Workshop. Extended Abstracts, Illinois State Geological Survey. Open-File Series 2004-8,

2004, (http://library.isgs.uiuc.edu/Pubs/pdfs/ofs/2009/ofs2009-04.pdf).

Bertotti G., Picotti V., Bernoulli D. and Castellarin A., From rifting to drifting: tectonic evolution of the South-Alpine upper crust from the Triassic to the Early Cretaceous, Sediment. Geol. 86, 1993, 53-76.

Bertotti G., Capozzi R. and Picotti V., Extension controls Quaternary tectonics, geomorphology and sedimentations of the N-Apennines foothills and adjacent Po Plain (Italy), Tectonophysics 282, $1997,291-301$.

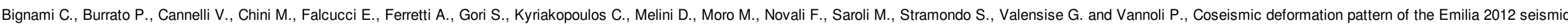
sequence imaged by Radarsat-1 interferometry, Ann. Geophys. 55 (4), 2012, 789-795, http://dx.doi.org/10.4401/ag6157.

Boccaletti M., Corti G. and Martelli L., Recent and active tectonics of the external zone of the Northern Apennines (Italy), Int. J. Earth Sci. 100, 2011, 1331-1348, http://dx.doi.org/10.1007/s00531-010-0545-y. Bongiorni D., La ricerca di idrocarburo negli alti strutturali mesozoici della Pianura Padana: l'-esempio di Gaggiano, Atti Tic Sci. Terra XXXI, 1987, 125-141.

Bonini L., Toscani G. and Seno S., Three-dimensional segmentation and different rupture behavior during the 2012 Emilia seismic sequence (Northern Italy), Tectonophysics 630, 2014, 33-42.

Bressan G., De Franco R. and Gentile F., Seismotectonic study of the Friuli (Italy) area based on tomographic inversion and geophysical data, Tectonophysics 207, 1992, 383-400.

Bressan G., Snidarcig A. and Venturini C., Present state of tectonic stress of the Friuli area (eastern Southern Alps), Tectonophysics 292, 1998, 211-227.

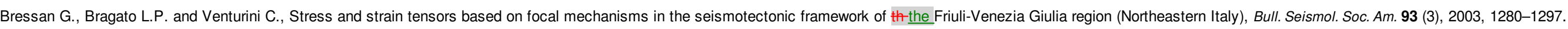

Burrato P., Ciucci F. and Valensise G., An inventory of river anomalies in the Po Plain, Northern Italy: evidence for active blind thrust faulting, Ann. Geophys. 46 (5), $2003,865-882$.

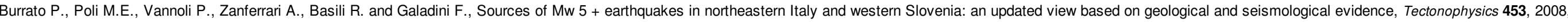
157-176.

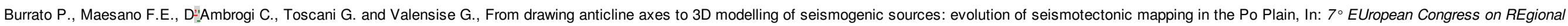
GEOscientific Cartography and Information Systems (EUREGEO), 12-15 June 2012, Bologna, 2012, (Available from: http://ambiente.regione.emilia-romagna.it/geologia-

en/temi/euregeo2012/presentations/09_Burrato_etal_Euregeo.pdf).

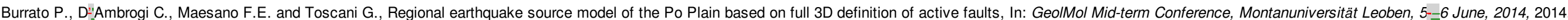
Carena S., Suppe J. and Kao H., Active detachment of Taiwan illuminated by small earthquakes and its control of first-order topography, Geology 30 (10), 2002, 935-938.

Carminati E. and Doglioni C., Alps vs. Apennines: the paradigm of a tectonically asymmetric Earth, Earth Sci. Rev. 112, 2012, 67-96.

Carminati E., Enzi S. and Camuffo D., A study on the effects of seismicity on subsidence in foreland basins: an application to the Venice area, Glob. Planet. Chang. 55, 2007, 237-250.

Carminati E., Scrocca D. and Doglioni C., Compaction-induced stress variations with depth in an active anticline: Northern Apennines, Italy, J. Geophys. Res. 115, 2010, B02401, http://dx.doi.org/10.1029/2009JB006395. Carulli G.B. and Ponton M., Interpretazione strutturale profonda del settore centrale Carnico-Friulano, Studi Geol. Camerti 1992, 275-284, (Special Volume, CROP 1-1A).

Casero P., Rigamonti A. and locca M., Paleogeographic relationship during Cretaceous between the Northern Adriatic area and the Eastern Southern Alps, Mem. Soc. Geol. Ital. 45, 1990, 807-814.

Cassano E., Anelli L., Fichera R. and Cappelli V., Pianura Padana, interpretazione integrata di dati Geofisici e Geologici, In: $73^{\circ}$ congresso Soc. Geol. It., Roma, 1986.

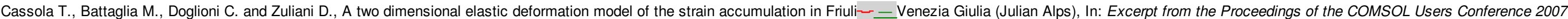
Grenoble, 2007

Castaldini D. and Panizza M., Inventario delle faglie attive tra I fiumi Po e Piave e il lago di Como (Italia Settentrionale), Quaternario 4 (2), 1991, 333-410. 
Castellarin A., Alps_=Apennines and Po Plain_-_Frontal Apennines relationships, In: Vai G.B. and Martini I.P., (Eds.), Anatomy of an Orogen, The Apennines and Adjacent Mediterranean Basins 2001, Kluver; London, 177-196.

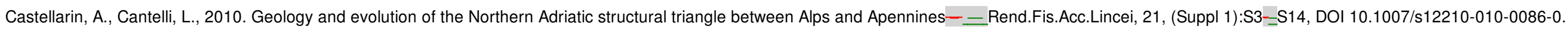

Castellarin A. and Vai G.B., Introduzione alla geologia strutturale del Sudalpino, In: Castellarin A. and Vai G.B., (Eds.), Guida alla gelogia del Sudalpino centro orientale, Guide Geol. Reg., Soc. Geol. It. 1982, 1-22.

Castellarin A. and Vai G.B., In: Wezel F.C., (Ed), The Origin of Arcs, 1986, Elsevier Sc. Pul., 253-280.

Castellarin A., Eva C., Giglia G. and Vai G.B.G.B., Analisi strutturale del Fronte Appenninico Padano, Giorn. Geol. Sez. 3॰ (47/1-2), 1986, 47-75.

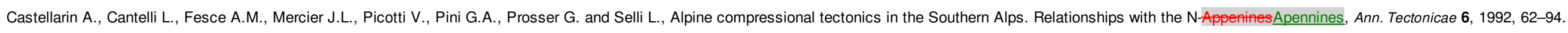

Castellarin A., Nicolich R., Fantoni R., Cantelli L., Sella M. and Selli L., Structure of the Hitespherelithosphere beneath the Eastern Alps (southern sector of the TRANSALP transect), Tectonophysics 414, $2006,259-282$.

Castello B., Selvaggi G., Chiarabba C. and Amato A., CSI Catalogo della sismicità italiana 1981-_2002, versione 1.1. INGV-CNT, Roma, http://csi.rm.ingv.it/ 2006.

Channell J.E.T., D=Argenio B. and Horvath F., Adria, the African promontory, in Mesozoic Mediterranean palaeogeography, Earth Sci. Rev. 15, 1979, $213-292$.

Chiarabba C., Jovane L. and DiStefano R., A new view of Italian seismicity using 20 years of instrumental recordings, Tectonophysics 395, 2005, 251-268.

Chiaraluce L., Valoroso L., Anselmi M., Bagh S. and Chiarabba C., A decade of passive seismic monitoring experiments with local networks in four Italian regions, Tectonophysics 476, 2009 , 85-98.

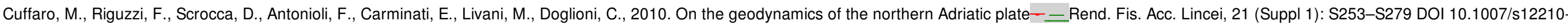
010-0098-9.

Dal Piaz G.V., Bistacchi A. and Massironi M., Geological outline of the Alps, Episodes 26, 2004, 175-180.

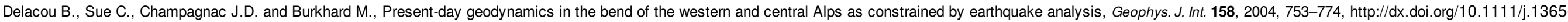
246X.2004.02320.x.

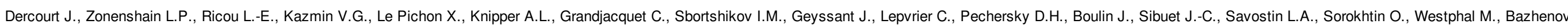

M.L., Laurer J.P. and Biju-Duval B., Geological evolution of the Tethys belt from Atlantic to Pamirs since the Lias, Tectonophysics 123, 1986, 241-315.

Devoti R., Esposito A., Pietrantonio G., Pisanil A.R. and Riguzzi F., Evidence of large scale deformation patterns from GPS data in the Italian subduction boundary, Earth Planet. Sci. Lett. 311 (3-4), 2011, 230-241,

http://dx.doi.org/10.1016/j.epsl.2011.09.034.

Dewey J.F., Pitman C., Ryan B.F. and Bonnin J., Plate tectonics and the evolution of the Alpine systems, Geol. Soc. Am. Bull. 84 (3), 1973, 137-180.

Di Bucci D. and Angeloni P., Adria seismicity and seismotectonics: review and critical discussion, Mar. Pet. Geol. 42, 2013, 182-190, http://dx.doi.org/10.1016/j.marpetgeo.2012.09.005.

Di Giovambattista R. and Tyupkin Y., The fine structure of the dynamics of seismicity before M > 4.5 earthquakes in the area of Reggio Emilia (Northern Italy), Ann. Geofis. 42 (5), 1999.

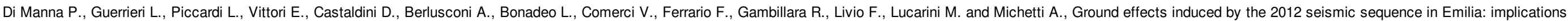
for seismic hazard assessment in the Po Plain, Ann. Geophys. 55, 2012, 4, http://dx.doi.org/10.4401/ag-6143.

Dischinger J.D. and Mitra S., Three-dimensional structural model of the Painter and East Painter reservoir structures, Wyoming fold and thrust belt, AAPG Bull. 90 (8), 2006, 1171-1185.

Doglioni C. and Bosellini A., Eoalpine and mesoalpine tectonics in the Southern Alps, Geol. Rundsch. 76 (3), 1987, 735-754.

Elter P. and Pertusati P., Considerazioni sul limite Alpi-_Appennino e sulle sue relazioni con l"arco delle Alpi occidentali, Mem. Soc. Geol. Ital. 12, 1973, 359-375.

Errico G., Groppi G., Savelli S. and Vaghi G.C., Malossa Field: a deep discovery in the Po Valley, Italy, AAPG Mem. 30, 1980, 525-538. 
Fantoni R., Bersezio R. and Forcella F., Alpine structure and deformation chronology at the Southern Alps--Po Plain border in Lombardy, Boll. Soc. Geol. Ital. 123, 2004, 463-476.

Galadini F., Poli M.E. and Zanferrari A., Seismogenic sources potentially responsible for earthquakes with M > 6 in the eastern Southern Alps (Thiene=-Udine sector, NE Italy), Geophys. J. Int. 161, 2005, 739-762.

Gelati R. and Gnaccolini, Evoluzione tettonico-sedimentaria della zona al limite tra Alpi a Appennino tra l'-inizio dell-'Ologocene e il Miocene medio, Mem. Soc. Geol. Ital. 24, 1982, 183-191.

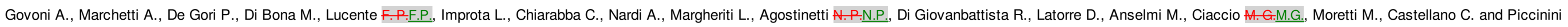

D., The 2012 Emilia seismic sequence (Northern Italy): imaging the thrust fault system by accurate aftershock location, Tectonophysics 622, 2014, 44-55, http://dx.doi.org/10.1016/j.tecto.2014.02.013.

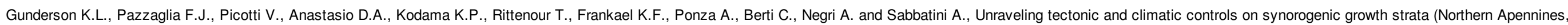
Italy), Geol. Soc. Am. Bull. 126 (3-4), 2013, 532-552, http://dx.doi.org/10.1130/B30902.1.

Han J., Yeon Y., Hyun H. and Hwang D., 3D Geological Model of Mining Area, http://www.asiageospatialforum.org/2011/proceeding/pps/Jonggyu\%20Han_AGF.pdf 2011.

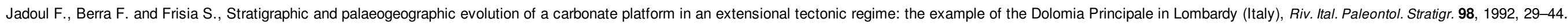

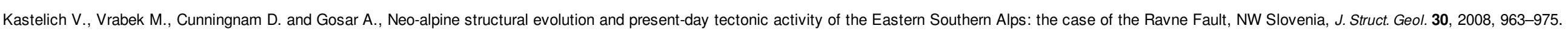

Laubscher H.P., Shallow and Deep Rotations in the Miocene Alps Tectonics, 15, 1022-1035, 1996.

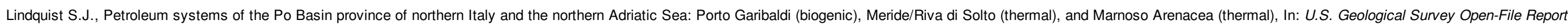
99-50-M, 1999, (19 pp., 15 figs., 3 tables).

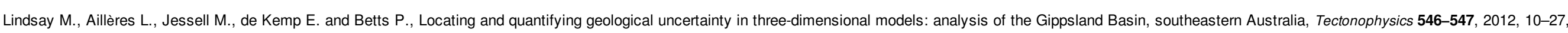
http://dx.doi.org/10.1016/j.tecto.2012.04.007.

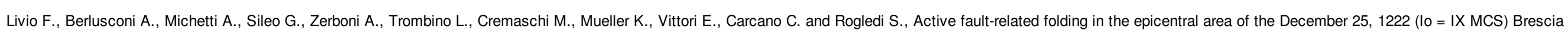
earthquake (Northern Italy): seismotectonic implications, Tectonophysics 476, 2009, 320-335.

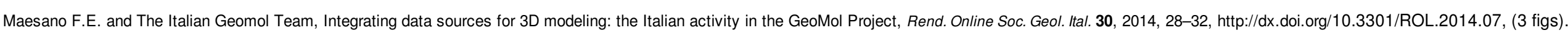

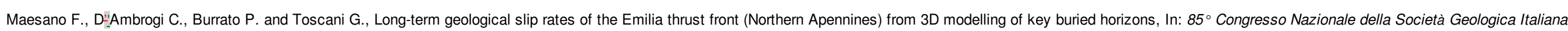
"L'Appennino nella geologia del Mediterraneo Centrale", 6-_8 September 2010, Pisa, 2010.

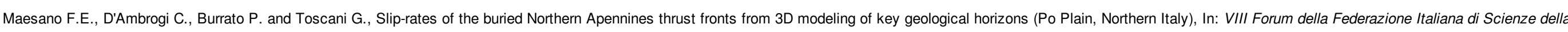
Terra, Geoitalia, 19-23 September 2011, Torino, 2011, (Plio-_Pleistocene only \& few pseudo 3D blocks from sections).

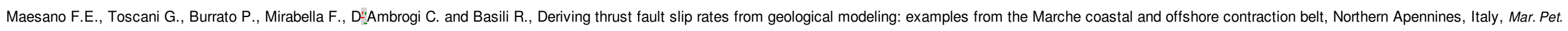
Geol. 42, 2013, 122-134, http://dx.doi.org/10.1016/j.marpetgeo.2012.10.008.

Maesano F.E., D'Ambrogi C., Burrato P. and Toscani G., Slip-rates of blind thrusts in the Po sedimentary basin (Italy), Tectonophysics 643, 2014, 8-25.

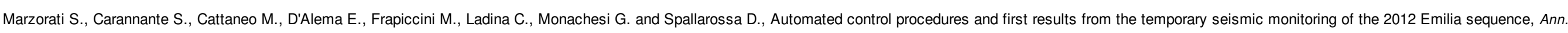
Geophys. 55, 2012, 4, http://dx.doi.org/10.4401/ag-6116.

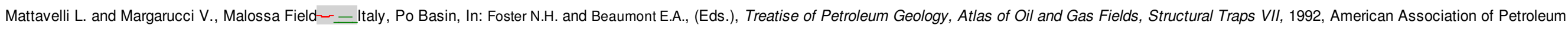
Geologists; Tulsa, OK, 119-137.

Mattavelli L. and Novelli L., Origin of the Po basin hydrocarbons, Mém. Soc. Géol. Fr. 151, 1987, 97-106.

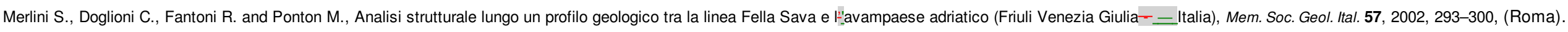




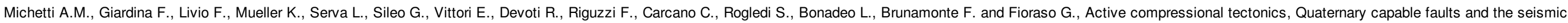
landscape of the Po Plain (N Italy), Ann. Geophys. 55 (5), 2012, 969-1001, http://dx.doi.org/10.4401/ag-5462.

Mitra S. and Leslie W., Three-dimensional structural model of the Rhourde el Baguel, AAPG Bull. 87 (2), 2003, 231-250.

Mitra S., Figueroa G.C., Hernandez Garcia J. and Murillo Alvarado A., Three-dimensional structural model of the Cantarell and Sihil structures, Campeche Bay, Mexico, AAPG Bull. 89 (1), 2005, 1-26.

Mitra S., Gonzalez A., Hernandez Garcia J. and Kajari G., Ek-Balam field: a structure related to multiple stages of salt tectonics and extension field, Algeria, AAPG Bull. 91 (11), 2007, 1619-1636.

Montone P., Mariucci M.T., Pondrelli S. and Amato A., An improved stress map for Italy and surrounding regions (central Mediterranean), J. Geophys. Res. 109, 2004, , B10410http://dx.doi.org/10.1029/2003JB002703.

Moratto L., Suhadolc P. and Costa G., Finite-fault parameters of the September 1976 M > 5 aftershocks in Friuli (NE Italy), Tectonophysics 536-537, $2012,44-60$.

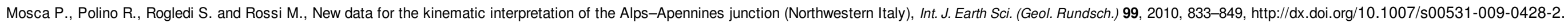

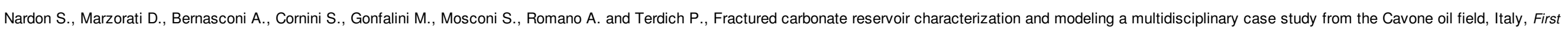
Break 9 (12), 1991, 553-565.

Nicolich, R., 2010. Geophysical investigation of the crust of the Upper Adriatic and neighbouring chains-_-Rend.Fis.Acc.Lincei, 21, (Suppl 1):S181-_S196, DOI 10.1007/s12210-010-0093-y.

Perotti G.R.C.R. Osservazioni sull':assetto strutturale del versante padano dell':Appennino Nord-Occidentale, Atti Tic Sci. Terra 34, $1991,11-22$.

Perotti G.R.C.R. and Vercesi P.L.P.L., Assetto tettonico ed evoluzione strutturale recente della porzione nord-occidentale dell’"Appennino Emiliano, Memorie Descrittive Carta Geologica d"Ittalia XLVI, 1991 , 313-326.

Peruzza L., Poli M.E., Rebez A., Renner G., Rogledi S., Slejko D. and Zanferrari A., The 1976-=1977 seismic sequence in Friuli: new seismotectonic aspects, Mem. Soc. Geol. Ital. 57, 2002, 391-400.

Pieri M., Storia delle ricerche nel sottosuolo padano fino alle ricostruzioni attuali, In: Cento anni di geologia Italiana, Volume Giubilare, 1 Centenario della Soc. Geol. Ital. $1881-1981$, Roma, 1984, 155-177.

Pieri M. and Groppi G., Subsurface geological structure of the Po Plain, Italy, Prog. Fin. Geodinamica CNR, pubbl.414 1981, 1-113.

Placer L., Contribution to the macrotectonic subdivisionofsubdivision of the border region between Southern Alps and External Dinarides, Geologija 41, 1999, 223-255, (Ljubljana).

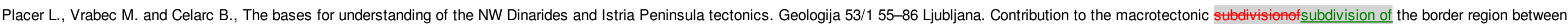
Southern Alps and External Dinarides, Geologija 41, 2010, 223-255, (Ljubljana).

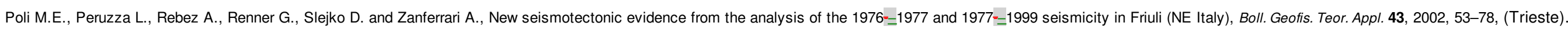
Ponton M., Architettura delle Alpi Friulane, 2010, Museo Friulano di Storia Naturale, Publ. No 52, Udine. ISBN: 9788888192529.

Ponza A., Pazzaglia F.J. and Picotti V., Thrust-fold activity at the mountain front of the Northern Apennines (Italy) from quantitative landscape analysis, Geomorphology 123, $2010,211-231$.

Ravaglia A., Seno S., Toscani G. and Fantoni R., Mesozoic extension controlling the Southern Alps thrust front geometry under the Po Plain, Italy: insights from sandbox models, J. Struct. Geol. 28, 2006, 2084e2096.

Ricci Lucchi F., The Oligocene to recent foreland basins of the northern Apennines, In: Allen P.A.P.A. and Homewood P., (Eds.), Foreland Basins, I.A.S. Special Publication 8, 1986, 105-139.

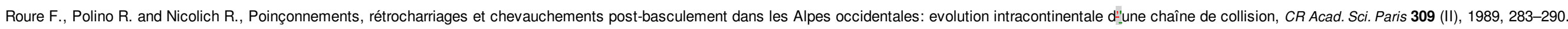

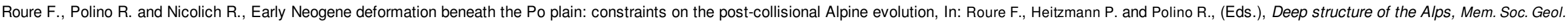
France 156, 1990, 309-322.

Rovida R., Camassi R., Gasperini P. and Stucchi M., In: CPTI11, the 2011 version of the Parametric Catalogue of Italian Earthquakes, Milano, Bologna, 2011, (http://emidius.mi.ingv.it/CPTI/).

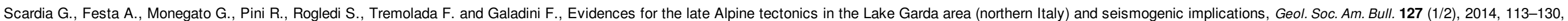


http://dx.doi.org/10.1130/B30990.1.

Schmid S., Fugenschuh B., Kissling E. and Schuster R., Tectonic map and overall architecture of the Alpine orogen, Eclogae Geol. Helv. 97, 2004, 93-117.

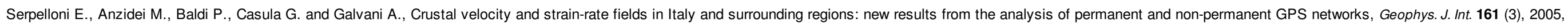
861-880.

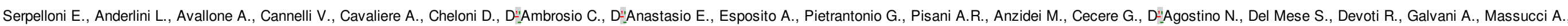

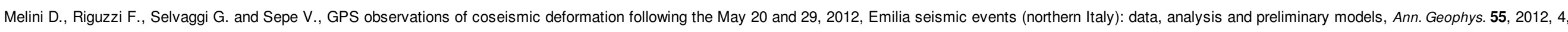
http://dx.doi.org/10.4401/ag-6168.

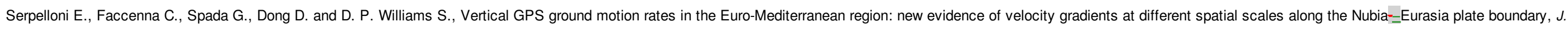
Geophys. Res. 118, 2013, 6003-6024, http://dx.doi.org/10.1002/2013JB010102.

Shao Y., Zheng A., He Y. and Xiao K., 3D geological modeling under extremely, complex geological conditions, J. Comput. 3, 2012, 699-705.

Toscani G., Seno S., Fantoni R. and Rogledi S., Geometry and timing of deformation inside a structural arc: the case of the western Emilian folds (Northern Apennine front, Italy), Boll. Soc. Geol. Ital. 125, 2006, 59-65.

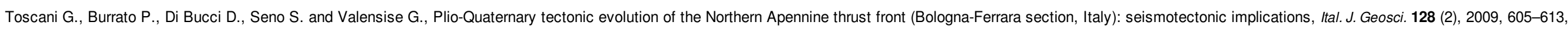
http://dx.doi.org/10.3301/IJG.2009.128.2.605.

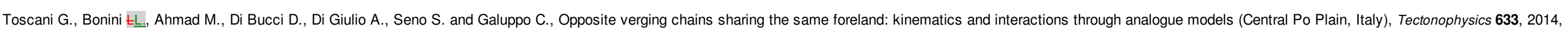
268-282, http://dx.doi.org/10.1016/j.tecto.2014.07.019.

Trumpy R., The timing of orogenic events in the Central Alps, In: De Jong K.A. and Scholten R., (Eds.), Gravity and Tectonics, 1973, Wiley and Sons; New York, 229-251.

Turrini C. and Rennison P., Structural style from the Southern Apennines!- hydrocarbon province-an integrated view, In: McClay K.R., (Ed), Thrust tectonics and hydrocarbon systems, AAPG Memoir 82, 2004, 558-578.

Turrini C., Dups K. and Pullan C., 2D and 3D structural modelling in the Swiss-_French Jura Mountains, First Break 27, 2009, 65-71.

Turrini C., Lacombe O. and Roure F., Present-day 3D structural model of the Po Valley basin, Northern Italy, Mar. Pet. Geol. 56, 2014, 266-289.

Turrini C., Angeloni P., Lacombe O., Ponton M. and Roure F., Three-dimensional seismo-tectonics in the Po Valley basin, northern Italy, 2015, Geopgysieat-Geophysical Research Abstract, EGU; Vienna.

Valcarce G., Zapata T., Ansa A. and Selva G., Three-dimensional structural modeling and its application for development of the El Porto-'n field, Argentina, AAPG Bull. 90 (3), $2006,307-319$.

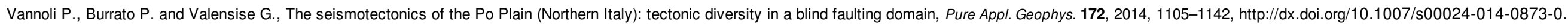

Venturini C., Cinematica neogenico-quaternaria del sudalpino orientale (settore friulano), Studi Geol. Camerti 1991, 109-113, (vol. spec. (1990), Camerino).

ViDEPI Project, http://unmig.sviluppoeconomico.gov.it/videpi/kml/webgis.asp.

Vignaroli G., Faccenna C., Jolivet L., Piromallo C. and Rossetti F., Subduction polarity reversal at the junction between the Western Alps and the Northern Apennines, Italy, Tectonophysics 450, 2008, 34-50.

Vouillamoz N., Sue C., Champagnac J. and Calcagno P., 3D cartography modeling of the Alpine Arc, Tectonophysics 579, 2012, 131-143, http://dx.doi.org/10.1016/j.tecto.2012.06.012.

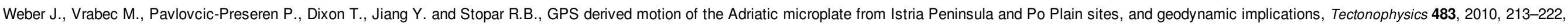
http://dx.doi.org/10.1016/j.tecto.2009.09.001. 
- Structure _earthquake associations are illustrated to review and discuss the complex seismicity across the region.

- A major step in the analysis of the Po Valley seismo-tectonics with respect to the previous studies

\section{Queries and Answers}

Query:

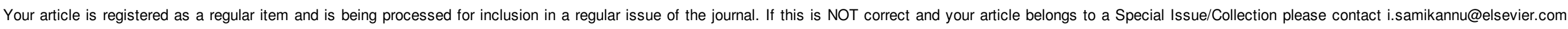
immediately prior to returning your corrections.

Answer: Yes

Query:

Please confirm that given names and surnames have been identified correctly.

Answer: Yes

Query:

The affiliation "IFP-EN, Rueil-Malmaison, France and Utrecht University, The Netherlands" has been split into two different affiliations. Please check and confirm if correct.

Answer: Yes

Query:

This sentence has been slightly modified for clarity. Please check and confirm if the meaning is still correct.

Answer: Yes

Query:

Please confirm that given names and surnames have been identified correctly

Answer: yes

Query:

Please check the captured keywords and amend if necessary.

Answer: Seismo-tectonics, 3D models, Earthquakes, Po Valley

Query

Journal style requires a minimum of 4 and maximum of 6 keywords. Please check and provide the necessary correction.

Answer: Seismo-tectonics, 3D models, Earthquakes, Po Valley 
The citation "Argnani et al., 2001" has been changed to match the author name/date in the reference list. Please check and correct if necessary.

Answer: ok

Query:

The citation "Gelati and Gnaccolini M., 1982" has been changed to match the author name/date in the reference list. Please check and correct if necessary.

Answer: ok

Query:

Citation "Livio et al. (2014)" has not been found in the reference list. Please supply full details for this reference.

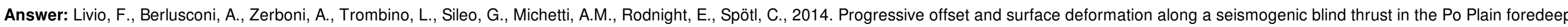
(Southern Alps, Northern Italy). American Geophysical Union ; doi : 10.1002/2014JB011112.

Query:

Citation "Bresciani and Perotti (2014)" has not been found in the reference list. Please supply full details for this reference.

Answer: Bresciani, I., Perotti, C.R., 2014. An active deformation structure in the Po Plain (N. Italy): the Romanengo anticline. American Geophysical Union; doi: $10.1002 / 2013 T C 003422$

Query:

Citations "Scognamiglio et al., 2012" and "Carannante et al., 2013" have not been found in the reference list. Please supply full details for these references.

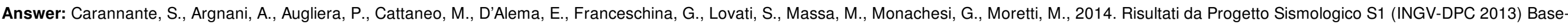
knowledge improvement for assessing the seismogenic potential of Italy Section n: D18/b2 Relocated seismicity in the Po Plain. Workshop Terremoto Emilia 2012 - Roma, 26 Maggio 201.

Query:

The citation "ViDEPI Project" has been changed to match the author name/date in the reference list. Please check and correct if necessary.

Answer: ok

Query:

Section "3.4" has been cited here but not found/provided. Please check and amend as necessary.

Answer: Section 4

Query:

Please check the data here and amend if necessary.

Answer: see also

Query:

Citation "Bosica and Shiner, 2013" has not been found in the reference list. Please supply full details for this reference.

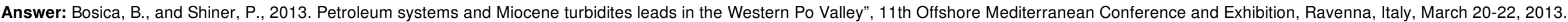


This sentence has been slightly modified for clarity. Please check and confirm if the meaning is still correct.

Answer: ....associations, being that uncertainty greater as investigation is performed across restricted structural domains.

Query:

Uncited reference: This section comprises references that occur in the reference list but not in the body of the text. Please position each reference in the text or, alternatively, delete it. Thank you.

Answer: please delete the reference

Query:

Please confirm that given names and surnames have been identified correctly

Answer: ok 